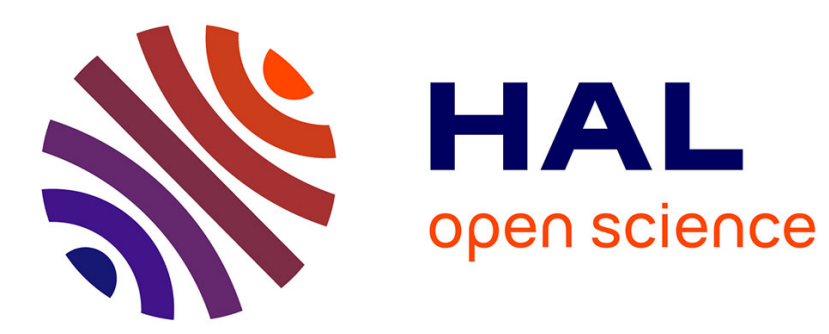

\title{
Mantle-derived magmas and magmatic Ni-Cu-(PGE) deposits
}

\author{
Nicholas Arndt, C.M. Lesher, G.K. Czamanske
}

\section{To cite this version:}

Nicholas Arndt, C.M. Lesher, G.K. Czamanske. Mantle-derived magmas and magmatic Ni-Cu-(PGE) deposits. Economic Geology, 100th Aniversary volume, pp.5-24, 2005. hal-00016864

\section{HAL Id: hal-00016864 \\ https://hal.science/hal-00016864}

Submitted on 12 Jan 2006

HAL is a multi-disciplinary open access archive for the deposit and dissemination of scientific research documents, whether they are published or not. The documents may come from teaching and research institutions in France or abroad, or from public or private research centers.
L'archive ouverte pluridisciplinaire HAL, est destinée au dépôt et à la diffusion de documents scientifiques de niveau recherche, publiés ou non, émanant des établissements d'enseignement et de recherche français ou étrangers, des laboratoires publics ou privés. 


\title{
Mantle-derived magmas and magmatic Ni-Cu-(PGE) deposits
}

\author{
N.T. Arndt' ${ }^{1}$, C.M. Lesher ${ }^{2}$ and G.K. Czamanske ${ }^{3}$
}

1 - LGCA, University Joseph Fourier, 1381 rue de la Piscine, 38401 Grenoble, France, arndt@ujf-grenoble.fr

2 - Mineral Exploration Research Centre, Department of Earth Sciences, Laurentian University, Sudbury, Ontario P3E6B5 Canada, mlesher@laurentian.ca

3 - 750 West Greenwich Place, Palo Alto, California 94303, USA, czamrandg@earthlink.net

\begin{abstract}
Magmatic $\mathrm{Fe}-\mathrm{Ni}-\mathrm{Cu} \pm$ platinum-group element (PGE) sulfide deposits form when mantlederived mafic and ultramafic magmas become saturated in sulfide and segregate immiscible sulfide liquid, commonly following interaction with crustal rocks. Although the metal contents of primary magmas influence ore compositions, they do not control ore genesis because the metals partition strongly into the sulfide liquid and because most magmas capable of segregating sulfide liquid contain sufficient abundances of ore metals. More important controls are the temperature, viscosity, volatile content, and mode of emplacement of the magma, which control the dynamics of magma emplacement and the degree of interaction with crust. By this measure, hightemperature, low-viscosity komatiites and tholeiitic picrites are most capable of forming $\mathrm{Ni}-\mathrm{Cu}$ (PGE) deposits, whereas lower-temperature, volatile-rich alkali picrites and basalts have less potential. In most deposits, ore formation is linked directly to incorporation of S-rich country rocks and only indirectly to contamination by granitic crust. However, the geochemical signature of contamination is easily recognized and is a useful exploration guide because it identifies magmas that had the capacity to incorporate crustal material. Several aspects of the ore-forming process remain poorly understood, including the control of mantle melting processes on the PGE contents of mafic-ultramafic magmas, the mechanisms by which sulfur is transferred from wall rocks to ores (bulk assimilation, incongruent melting, and/or devolatilization), the distances and processes by which dense sulfide melts are transported from where they form to where they become concentrated (as finely-dispersed droplets, as segregated layers, or by deformationdriven injection of massive sulfide accumulations), and the dynamic processes that increase the metal contents of the ores.
\end{abstract}

\section{Introduction}

Magmatic ore deposits form through processes that are, for the most part, normal aspects of the crystallization of mafic to ultramafic magmas. Such magmas form through melting in hotterthan-normal parts of the mantle, and they rise towards the crust because their density is, on average, less than that of the enclosing mantle rocks. On reaching the crust, they may stall in magma chambers at density discontinuities and crystallize as intrusive bodies, or they may pass through the chambers to erupt at the surface as lava flows. Most commonly, the resultant rocks consist almost entirely of silicate minerals with only minor amounts of oxides and other accessory minerals. However, in some cases, minor differences in the composition of the mantle source, the mode or degree of partial melting, the timing and mechanisms of emplacement and crystallization, or the compositions of assimilated crustal materials result in the accumulation of economic abundances of ore metals. The key to explaining the origins of magmatic ore deposits 
therefore lies in understanding the factors that perturb the normal cycle of partial melting, magma transport, magma-rock interaction, and crystallization.

There are four critical phases in the formation of magmatic $\mathrm{Fe}-\mathrm{Ni}-\mathrm{Cu} \pm$ platinum-group element (PGE) sulfide deposits (Naldrett, 1989a,b, 2004). 1) A metal-bearing, mafic or ultramafic parental magma forms by partial melting of the mantle, separates from the solid residue, ascends through the asthenospheric and lithospheric mantle, and intrudes into the crust or erupts on the surface. 2) The magma interacts with its wall rocks, losing heat, forming a hybrid or contaminated magma, and commonly incorporating crustal $\mathrm{S}$, processes that result in the generation or segregation of an immiscible sulfide melt. 3) The sulfide melt interacts dynamically with a much larger mass of silicate magma, a process that increases the tenors of ore metals, especially for highly chalcophile elements. 4) Finally, the metal-rich sulfide liquid accumulates in sufficient quantity to form an economic deposit.

A question fundamental to the study of magmatic ore deposits is whether the parental magmas must have unusually high contents of ore metals in order to form an ore deposit, or whether the ore-forming process depends more on the history of the mantle-derived magma, particularly the manner in which it interacts with wall rocks during its passage towards the surface. In the following sections, we discuss these aspects of the ore-forming process, but first we provide some background information about magmatic $\mathrm{Ni}-\mathrm{Cu}$-(PGE) deposits related to mafic-ultramafic rocks.

\section{The main types of primary magmatic Ni-Cu-(PGE) mineralization in mafic- ultramafic rocks}

$\mathrm{Ni}-\mathrm{Cu}-(\mathrm{PGE})$ mineralization occurs as three major primary (magmatic) types and two secondary types (Lesher and Keays, 2002). Only the primary types will be considered here. We have chosen not to describe individual deposits, even briefly, because such descriptions are provided in other chapters (Barnes et al., this volume; Cawthorn et al., this volume) and in many reviews (e.g., Lesher, 1989; Naldrett, 1989a,b, 2004; Lesher and Keays, 2002), and because we wish to focus on the processes that are fundamental to ore genesis. Instead we summarize the principal characteristics of magmatic Ni-Cu-(PGE) deposits in Table 1 and discuss aspects of individual deposits in later sections in order to illustrate specific features of the ore-forming process.

Type I mineralization forms early in the crystallization history of the host unit and comprises layers of massive and/or disseminated Fe-Ni-Cu-(PGE) sulfides at or near its base (Type 1a) and associated stringers in the footwall rocks (Type $\mathrm{Ib}$ ). Deposits of this type are found in a range of different geological environments, and, as will be explained later, interaction with wall rocks probably plays an essential role in the formation of the ores.

Type II mineralization forms later in the crystallization history of the host units and comprises stratabound layers of coarse, disseminated, blebby- or globular- textured sulfides (Type IIa), fine-grained disseminated sulfides (Type IIb), very fine-grained "cloudy" or "dusty" sulfides (Type IIc), or veins/pods of disseminated or stockwork sulfides (Type IId).

Type III mineralization forms during fractional crystallization of thick flows and sills, and comprises relatively thin stratiform layers ("reefs") that are commonly enriched in PGE. Although most such occurrences are uneconomic, processes operating within very large layered intrusions may produce economic concentrations. Although many of the ore-forming processes 
discussed in this paper are relevant to the generation of the parental magmas of Type III PGE deposits, the formation of these deposits commonly appears to have involved processes other than strictly magmatic. Because the focus of this paper is on Ni-Cu-(PGE) deposits, Type III deposits will not be considered in much detail.

\section{Host Rocks and Parental Magmas}

With the exception of the Sudbury deposits, which formed in a crustal impact melt, magmatic $\mathrm{Ni}-\mathrm{Cu}$-(PGE) deposits are hosted by a wide range of olivine-bearing mantle-derived rocks (Lesher and Stone, 1996; Lesher and Keays, 2002; see also Naldrett, 1989; 2004). These include Al-undepleted komatiite (e.g., Kambalda in Australia and Alexo, and Thompson in Canada), Aldepleted komatiite (e.g., Forrestania in Australia), komatiitic basalt (e.g., Raglan, Canada), ferropicrite (e.g., Pechenga, Russia), tholeiitic picrite (e.g., Noril'sk-Talnakh, Russia), and highAl basalt (e.g., Voisey's Bay, Canada). The unusual, siliceous, high-Mg magmas parental to the Bushveld Complex in South Africa and the Stillwater Complexe in the USA have been interpreted as crustally contaminated komatiite (Irvine, 1977; Barnes, 1989; Maier et al., 2000), boninite (Hatton and Sharpe, 1988), or a partial melt of metasomatised sub-continental lithosphere (Hamlyn and Keays, 1986; Lambert and Simmons, 1987). Virtually absent from the spectrum of mafic to ultramafic magmas that host major Ni-Cu-(PGE) deposits are alkali basalts and alkali picrites.

Given such diversity of magma types, it can be asked which features, if any, make a magma predisposed to form a Ni-Cu-(PGE) deposit. The Siberian flood basalt province, which hosts the Noril'sk-Talnakh deposits, is one of the largest known continental volcanic provinces, but it is composed dominantly of basaltic to picritic lavas like those in many other volcanic provinces. Yet, despite intensive exploration, similar ores have not been discovered elsewhere. There are some differences, however, in the broad tectonic setting and in the types of rocks within the sedimentary sequence (notably, thick beds of anhydrite) that underlie and host the ore-bearing intrusions in the Noril'sk-Talnakh region. Echoing the "nature versus nurture" debate, we repeat the question posed in the introduction: is there any characteristic of a mantle-derived magma that makes it particularly predisposed to generate an economic Ni-Cu-(PGE) deposit (metal content, degree of sulfur saturation, physical characteristics, etc.) or does the formation of a deposit depend principally or entirely on events that affect the magma during its passage through the lithospheric mantle and crust?

\section{What gives magma "ore potential"?}

To form an economic Ni-Cu-(PGE) deposit, the primary mantle-derived magma must contain sufficient ore metals and must be capable of being driven to sulfide saturation. If the magma is too undersaturated in sulfide and/or does not interact with sufficient external S, it may not reach sulfide saturation until crystallization is well advanced, resulting in only small amounts of Types IIb or IIc interstitial disseminated sulfides. If the metal abundances in the magma are too low or if too large an amount of sulfide melt interacts with too small an amount of magma, the sulfide may not contain high enough metal tenors to be economic. A key point is that although an immiscible sulfide phase is a normal segregation product in most mafic-ultramafic systems, it usually segregates in only very small amounts because of limitations on the abundance of $S$ in the magma, and usually at a late stage during the crystallization of the magma. Thus, the magma 
must be driven to sulfide saturation by contamination, with or without the addition of external $\mathrm{S}$, to not only saturate the magma in sulfide, but to form large enough amounts of a molten immiscible sulfide liquid (see discussion by Lesher and Campbell, 1993).

As a consequence, the capacity of a magma to form an economic $\mathrm{Ni-Cu}$-(PGE) deposit is controlled mainly by 1 ) the abundances of ore metals in the magma, 2) the sulfide saturation state of the magma, and 3) the capacity of the magma to interact with its surroundings. In practice, the ability of magma to interact with wall rocks depends on the nature of the wall rocks, the mode of emplacement, and the composition, temperature, viscosity, and volatile content of the magma itself (see Huppert and Sparks, 1985; Lesher et al., 2001).

\section{Compositions of mantle-derived magmas}

The compositions of mafic-ultramafic magmas are influenced by: 1) the composition of the source, which may vary with the degree of previous melting or the type and extent of metasomatism; 2) the type of melting (e.g., fractional, equilibrium); 3) the conditions of melting, particularly the temperature, pressure, and types and abundances of volatile components, and 4) the nature of any contamination, mixing, or crystallization processes that occur during ascent and emplacement. In combination, the first three factors control the degree of partial melting, the composition of the primary melt, and the types and compositions of residual phases. Particularly important in the context of ore formation is the presence or absence, in the residue of partial melting, of oxide, sulfide, and/or alloy phases that concentrate ore metals.

Experimental and empirical studies (see reviews by Carroll and Webster, 1994; Naldrett, 2004; $\mathrm{Li}$ and Ripley, in press) have shown that the solubility of sulfide (i.e., $\mathrm{S}^{2-}$ content at sulfide saturation) in mafic-ultramafic magmas increases with increasing temperature, $a \mathrm{FeO}$, and $f \mathrm{~S}_{2}$, and decreases with increasing pressure, $f_{2}, a \mathrm{SiO}_{2}$, and $a \mathrm{Na}_{2} \mathrm{O}$, and that the solubility of sulfate (i.e., $\mathrm{S}^{6+}$ content at sulfate saturation) increases with increasing $f \mathrm{O}_{2}$ and alkalinity. Importantly, the solubility of $\mathrm{S}$ as sulfate may be up to 10x greater than the solubility of $\mathrm{S}$ as sulfide (Jugo et al., 2005). However, because more studies have been carried out on basaltic compositions under more reduced conditions, our knowledge of $S$ solubility in basalts is fairly well established, but our knowledge of S solubility in other magma types is less well constrained.

\section{Source Composition}

Mantle peridotite, which is the source for most mafic-ultramafic magmas, varies in composition but consists primarily of olivine, orthopyroxene, clinopyroxene, and an aluminous phase (plagioclase at $<0.9 \mathrm{GPa}$, spinel at $0.9-3 \mathrm{GPa}$, and garnet at $>3 \mathrm{GPa}$ ). Minor phases include hydrous silicates, carbonates, other oxides and, crucially in the case of Ni-Cu-(PGE) deposits, sulfide(s) and/or PGE-rich alloy(s). There is considerable debate about the composition and heterogeneity of the mantle and how it has changed with time. Most komatiites, tholeiitic picrites, and mid-ocean ridge basalts are depleted in highly incompatible lithophile elements (Cs, $\mathrm{Rb}, \mathrm{U}, \mathrm{Th}, \mathrm{Nb}$, and light rare earth elements - LREE) relative to moderately incompatible lithophile elements ( $\mathrm{Zr}, \mathrm{Hf}, \mathrm{Ti}, \mathrm{HREE})$ and have positive $\mathrm{Wd}$ values, indicating that they were derived from sources with long-term depletion of these elements. Ferropicrites and many alkali magmas, on the other hand, are enriched in Fe, Ti, and highly incompatible lithophile elements and are thought to be derived from correspondingly enriched sources (e.g., Hanski, 1992; Gibson

et al., 2000). Sulfur commonly behaves as an incompatible or fluid-mobile element and is 
present in high concentrations in enriched sources. As explained in a later section, this has important implications for our understanding of the concentrations of chalcophile elements in mantle-derived magmas.

\section{Melting Mechanisms}

Melting can occur via a variety of different physical processes, including: 1) equilibrium (batch) melting in which the melt remains in equilibrium with the source, resulting in only moderate fractionation of highly from moderately incompatible elements; 2) fractional melting, in which the melt is continuously extracted and continually isolated from the source as it forms, resulting in progressive depletion of the more incompatible elements and pronounced fractionation of highly from moderately incompatible elements; and 3) critical melting, a variant of fractional melting in which a fraction of the melt is retained in the source, resulting in less pronounced fractionation of highly from moderately incompatible elements. Following extraction, fractional melts only rarely pass directly to the surface; normally they pool or mix with other melts, to form hybrid magmas with compositions similar to those of batch melts.

Most Archean komatiites are moderately depleted in highly incompatible elements and have been interpreted to have formed by high-degree (30-60 percent) partial melting of depleted mantle either through equilibrium melting (e.g., Herzberg and O'Hara, 1995; Sproule et al., 2001) or fractional melting (Arndt et al., 1998; Arndt, 2003). Cretaceous komatiites and picrites from Gorgona Island, part of the Caribbean oceanic plateau, are strongly depleted in highly incompatible elements and have been interpreted to have formed as unpooled fractional melts (Arndt et al., 1998; Révillon et al., 2000). In contrast, picrites from Curacao, another part of the Caribbean plateau, have flat REE profiles and are interpreted to have formed as pooled fractional melts (Révillon et al, 2000). Alkali basalts and picrites form through low to moderate degrees of melting of heterogeneous mantle sources that commonly contain recycled oceanic crust or sediment (Hofmann and White, 1982; Zindler and Hart, 1986).

\section{Metal Partitioning}

The abundance of PGE in magmas depends principally on the nature and abundance in the melting residue of phases such as sulfides, oxides, and alloys, which are capable of retaining these elements. The distribution of the ore metals between these phases is governed by their partition coefficients. Keays $(1982,1995)$ divided the platinum-group elements into two groups: Pd-group PGE (PPGE: Pd, Pt, and Rh), which, in sub-solidus peridotite, are hosted mainly by $\mathrm{Cu}$-rich sulfides, and Ir-group PGE (IPGE: Ru, Ir, Os), which are hosted mainly by Fe-Ni sulfide and metal alloys. Platinum-group elements are very chalcophile $\left(\mathrm{D}_{\mathrm{PGE}}\right.$ sulfide-silicate $\sim 10^{4}-10^{5}$ : Fleet et al., 1996; Ballhaus et al., 1994; Peach et al., 1994) and extremely siderophile $\left(\mathrm{D}_{\mathrm{PGE}}^{\text {sulfide-silicate }}\right.$ $\sim 10^{5}-10^{6}$ : O'Neil et al., 1995). Experimental, theoretical, and empirical studies (e.g., Peach et al., 1994; Fleet et al., 1996; Lesher and Campbell, 1993) have shown that sulfide-silicate partition coefficients for the chalcophile elements decrease with increasing $f \mathrm{O}_{2} / f \mathrm{~S}_{2}$. Although $\mathrm{Cu}$ partition coefficients are lower than those for the PGE $\left(\mathrm{D}_{\mathrm{Cu}}^{\text {sulfide-silicate }} \sim 10^{3}\right), \mathrm{Cu}$ is also hosted mainly in sulfides. Nickel is both chalcophile and lithophile, and it is partitioned between sulfides $\left(\mathrm{D}_{\mathrm{Ni}}^{\text {sulfide- }}\right.$

silicate $\sim 10^{2}-10^{3}$ ) and olivine $\left(\mathrm{D}_{\mathrm{Ni}}{ }^{\text {olivine-silicate }} \sim 2\right.$ in picritic to komatiitic liquids (Kinzler et al., 1990). The effect of pressure on sulfide-silicate partition coefficients is not well constrained. Metalsilicate partition coefficients for $\mathrm{Ni}$ and Co decrease with increasing pressure (Dingwell et al., 
1999), whereas metal-silicate partition coefficients for Pd, Pt, and Ir appear independent of pressure (Holzheid et al., 1998).

If sulfides, oxides, or alloys are retained in the residue during partial melting of the mantle, a significant proportion of the chalophile elements will remain in these phases and concentrations in partial melts will be low. Only when these phases are absent will the magma contain high abundances of elements such as $\mathrm{Ni}, \mathrm{Cu}$, and PGE.

\section{Melting the Mantle}

Batch melting of mantle peridotite is illustrated in Figure 1a. At low pressures and at relatively low degrees of melting (up to about 20 percent), all major silicate phases as well as oxides and sulfides contribute to the melt, which has a basaltic composition. As the degree of melting increases, garnet and clinopyroxene melt completely, and as more magnesian orthopyroxene and olivine enter the melt, the magma composition changes to picritic and finally to komatiitic. Increasing pressure changes the phase relations such that at high pressures the composition of a low-degree melt resembles that of a picrite or even a meimechite (alkali ultramafic lava from Siberia: Arndt et al., 1995, 1998). Many experimental studies show that at temperatures above the solidus of the silicate assemblage, the sulfide phase melts to form a homogenous immiscible liquid (see review by Naldrett, 2004).

As the degree of partial melting increases during the formation of the picritic and komatiitic magmas that host most magmatic Ni-Cu-(PGE) deposits, the sulfide phase progressively dissolves in the silicate liquid (Fig. 1b); when the degree of melting exceeds 15 to 25 percent, depending primarily on the $\mathrm{S}$ content of the peridotite, sulfide totally dissolves into the partial melt (e.g. Wendlandt, 1982; Naldrett and Barnes, 1986; Keays, 1995; Rehkämper et al., 1999). At low degrees of melting, when sulfide is retained in the residue, the PGE contents of the silicate melt are low, and only when the sulfide is eliminated from the source do PGE contents reach high levels (Fig. 1b). Alkali magmas are believed to form from more oxidized source materials (Carmichael, 1991), under conditions of high alkalinity and high $\mathrm{fO}_{2}$ that destabilizes the residual sulfide. As a consequence, sulfide may be consumed at low degrees of partial melting (e.g., Carroll and Webster, 1994; Sisson, 2003; Jugo et al., 2005) and the melt may contain high PGE contents. Under reducing conditions, PGE alloys are retained in the residue to high degrees of partial melting and these phases can fractionate the different groups of PGE. Crspinel, which may concentrate IPGE, also appears to persist as a solid phase in the residue to relatively high degrees of melting (Jacques et al., 1979).

\section{Chalcophile-element contents and sulfide saturation levels of mantle melts: theoretical considerations}

From the above-mentioned experiments and geochemical studies, the Ni-Cu-PGE contents of many mantle-derived melts can be predicted (Naldrett and Barnes, 1986; Keays, 1995; Lightfoot and Hawkesworth, 1997; Rehkämper et al., 1999; Momme et al., 2002). These are summarized in Table 2 and Figures 1b,c. At low to moderate degrees of melting of reduced sources, highly chalcophile elements such as $\mathrm{Cu}$ and PPGE partition strongly into the sulfide and alloy phases that remain in the residue, and the concentrations of these metals in the melt remain very low. Only when the sulfide totally disappears do concentrations of the highly chalcophile elements 
reach high levels in the melt. Rehkämper et al. (1999) adopted McDonough and Sun's (1995) estimate of the sulfur content of primitive mantle peridotite $(200-300 \mathrm{ppm})$ and calculated that sulfide disappears into the melt at 17 to 25 percent partial melting. Other authors have suggested that depleted mantle peridotite, which is the source of many mafic-ultramafic magmas, may contain as little as 125 ppm S (e.g., O'Neill et al., 1995), which would lower the degree of melting required to consume all of the sulfide (see discussion by Lesher and Stone, 1996). Nickel also partitions into sulfide, but less strongly than $\mathrm{Cu}$ and PPGE, and it also partitions into olivine, so its abundance increases more gradually with the degree of partial melting. The behavior of IPGE is more complicated, because they partition into olivine and into alloys that are retained with olivine. Their behavior is normally similar to that of $\mathrm{Ni}$, but they are sometimes retained even at very high degrees of partial melting (see Barnes et al., 1995; Lesher and Stone, 1996). On this basis, it can be predicted that the degree of partial melting exerts a strong control on the $\mathrm{Ni}-\mathrm{Cu}$-PGE contents of mantle-derived magmas. Non-alkalic magmas formed by low-degree partial melting under relatively reduced conditions should contain very low abundances of PPGE, low abundances of $\mathrm{Cu}$, and low to moderate abundances of $\mathrm{Ni}$; magmas formed by moderate degrees of partial melting should contain the highest abundances of PPGE and $\mathrm{Cu}$, and moderate abundances of Ni and IPGE; and magmas formed by high degrees of partial melting should contain low abundances of $\mathrm{Cu}$ and PPGE (owing to dilution) and high abundances of $\mathrm{Ni}$ and IPGE (owing to continued melting of olivine \pm alloys) (Fig. 1b).

Estimating the amount of partial melting that produced a given magma is not straightforward. If the composition of the source and the melting mechanism (e.g., equilibrium or fractional) are known, the degree of melting can be estimated from the incompatible trace-element contents of the magma. However, as noted above, the sources and melting mechanisms of mafic-ultramafic magmas vary considerably.

As a first step in estimating the degree of partial melting involved during the formation of various types of mafic and ultramafic magmas, we assume that the source had the composition of primitive mantle (present depleted mantle + continental crust: Hofmann, 1989; McDonough and Sun, 1995). This source probably did not exist in the mantle when any of these magmas actually formed, but it is a well-defined reference source, so we can use it to illustrate how the degree of melting varies. Using the concentrations of two incompatible rare earth elements (La and Sm, normalized to their abundances at 15 percent $\mathrm{MgO}$ to eliminate the effects of fractional crystallization, as is commonly done for mid-ocean ridge basalts), we estimate that the degree of melting ranges from less than 1 percent for meimechites to more than 50 percent for some komatiites (Fig. 2). If other source compositions were chosen, these values would change: an enriched source would produce similar concentrations at higher degrees of melting, whereas a depleted source would produce similar concentrations at lower degrees of melting. Variations in the melting mechanism (i.e., equilibrium or fractional) and the $f \mathrm{O}_{2}$ and alkali contents of the magma would also affect the result.

As a next step, we calculated the degrees of melting assuming more realistic sources for two endmember magmas: a depleted source for a 30 percent $\mathrm{MgO}$ komatiite and an enriched source for meimechite (Table 3). The extent of melting to produce the komatiite from such a source ranges from about 15 percent for fractional melting to 50 percent for equilibrium melting. The enriched source contains 10 percent of a basaltic component (eclogite under mantle conditions) with a La content 100 times greater than that of primitive mantle, giving a source with 10.9 times the La content of primitive mantle. This source could produce meimechite at 11 percent equilibrium 
partial melting, rather than the 0.1 percent required for the primitive mantle source. However, as the basaltic component increases, the $\mathrm{MgO}$ content of the source decreases. With a 10 percent basaltic component, the source contains only 35 wt percent $\mathrm{MgO}$ and such a source is unlikely to yield meimechitic liquids that contain up to $25 \mathrm{wt}$ percent $\mathrm{MgO}$. In addition, because sulfide enters the melt at low degrees of melting ( $\mathrm{S}$ behaves as an incompatible element), the depleted source should be poorer in $\mathrm{S}$ and the enriched source richer in $\mathrm{S}$.

\section{Sulfide saturation levels of mafic-ultramafic magmas}

Once magma escapes from its mantle source and ascends towards the surface, both its temperature and the confining pressure decrease, as shown in Figure 3. During passage to the surface, the influence of declining pressure on the sulfur solubility overwhelms that of decreasing temperature (Helz, 1974; Wendlandt, 1982; Mavrogenes and O'Neill, 1999). As a result, magmas become progressively more undersaturated in sulfide as they rise towards the surface (Lesher and Groves, 1986) (Fig. 3).

The degree of sulfide undersaturation has an important influence on the capacity of the magma to form an economically viable ore deposit. If a sulfide-undersaturated magma is to generate an immiscible sulfide liquid, either the solubility of sulfide in the magma must be significantly reduced or significant amounts of $\mathrm{S}$ must be added. If sulfide is to accumulate efficiently to form a massive sulfide deposit, the sulfide melt must segregate early in the crystallization sequence, before abundant silicate minerals crystallize and trap the sulfides. If the magma is close to sulfide saturation, sulfide melt may segregate as soon as the magma enters the lithosphere and begins to cool. Under these conditions, the sulfide melt segregates deep in the crust, leaving the ore metals at depths inaccessible to mining, unless they are tectonically transported to shallower crustal levels or unless erosion exposes deeper portions of the crust. On this basis, it can be predicted that sulfide deposits are most likely to form either deep in the crust from magmas that are not too far from sulfide saturation, or at shallower levels from sulfide-undersaturated magmas that have access to large amounts of external sulfur.

\section{Chalcophile-element contents and sulfide saturation levels of mantle melts: observations}

Figure 4 shows the conditions of formation of various types of mafic-ultramafic magmas, with emphasis placed on factors that directly influence the potential of the magma to produce a Ni$\mathrm{Cu}$-(PGE) deposit. The degree of partial melting should influence the metal content, as explained in an earlier section; the depth of melting, which controls the pressure drop that the magma undergoes as it rises toward the surface, influences the level of sulfide saturation. Our estimates of the state of sulfide saturation of the unfractionated magmas when they reach crustal levels are also given in Table 2.

From these parameters one might predict that the magmas most likely to form sulfide deposits are tholeiitic picrites, because these magmas form at degrees of melting sufficient to remove all of the sulfide in the source (and therefore some of the Ni and IPGE, and almost all of the Cu and PPGE), yet are not too undersaturated in sulfide when they reach the crust. Mungall (1999) has suggested that Fe-rich magmas (e.g., ferropicrites and Fe-tholeiites) have the greatest potential to form magmatic $\mathrm{Ni}-\mathrm{Cu}$-(PGE) deposits because their high Fe contents permit them to dissolve more $\mathrm{S}$. However, the amount of $\mathrm{S}$ that can be dissolved in the magma is quite small and does 
not appear to be a significant control in most deposits. Nevertheless, the higher Fe contents of these magmas may permit them to dissolve all of the sulfide in the source at lower degrees of partial melting, which may explain their high $\mathrm{Ni}, \mathrm{Cu}$, and PGE contents (see Lesher and Stone, 1996).

Komatiitic magmas might be considered less likely to form magmatic Ni-Cu-(PGE) deposits, because they should be strongly undersaturated in sulfide at crustal levels. However, as explained below, komatiitic magmas are more capable of melting wall rocks and incorporating external sulfur than most other magma types, and, in appropriate volcanological and stratigraphic settings, often host Ni-Cu-(PGE) deposits (Lesher, 1989).

Alkali picrites and meimechites might be dismissed because they formed by low-degree partial melting, but as noted above, the higher alkalinities and oxygen fugacities may have destabilized sulfides and allowed them to be consumed at lower degrees of partial melting.

In order to further explore these ideas, we compiled chalcophile-element compositions for a series of mafic and ultramafic samples (Fig. 5). The data include the two main types of komatiite (Al-undepleted and Al-depleted), tholeiitic basalts and picrites, alkali basalts and picrites, and meimechites (sources of data are given in the figure caption). These data indicate that maficultramafic magmas may be subdivided into several broad groups on the basis of the abundances and ratios of highly chalcophile or siderophile elements.

\section{Komatiites}

Most komatiites have high $\mathrm{Ni}$ and IPGE contents and moderate $\mathrm{Cu}, \mathrm{Au}$, and PPGE contents, consistent with their having formed by high-degree melting that left no sulfide in the source (Keays, 1982; Barnes et al., 1985). Maier et al. (2003) have shown that Al-depleted komatiites in the 3.5 Ga Barberton area have lower PPGE contents than Al-undepleted komatiites such as those common in $2.7 \mathrm{Ga}$ greenstone belts (Fig. 5) and suggested that they formed by moderate degrees of partial melting ( 30 percent) that left some sulfide in the residue. Their IPGE contents, however, are very similar to those in Al-undepleted komatiites (Fig. 5), which is inconsistent with a sulfide retention model (Table 2). Sproule et al. (2001; in press) have shown that Al-depleted komatiites in the Abitibi greenstone belt, which are less magnesian and appear to have been derived by lower degrees of partial melting than Barberton Al-depleted komatiites, have broadly similar PGE abundances and Pd/Ir ratios to those of associated Al-undepleted komatiites, suggesting that the amounts of melting for both magma types were sufficient to consume all of the sulfide in the sourceand that some other process must have depleted PPGE in Barberton Al-depleted komatiites.

\section{Basalts}

Most mid-ocean ridge basalts and alkali basalts have low to very low $\mathrm{Ni}, \mathrm{Pd}$ and Ir contents and widely variable Pd/Ir ratios (Fig. 5 and Table 2). Their parental magmas appear to have been derived by low to moderate degrees of partial melting under conditions that left sulfide in the source. (e.g., Crocket, 1979, 2002; Keays, 1982, 1995; Rehkämper et al., 1999). Continental flood basalts have moderate Ir contents, but high $\mathrm{Pd}$ contents (Fig. 5) and high $\mathrm{Pd} / \mathrm{Ir}$ ratios, consistent with derivation by moderate-degree partial melting that left no sulfide in the source, followed by assimilation-fractional crystallization. 


\section{Meimechites and Alkali Picrites}

Meimechites and alkali picrites have Os and Ir contents that on average are just as high as, or higher than, those in komatiites, and Pd and Re contents that are only slightly lower than those in Al-undepleted komatiites and in many cases higher than those of Al-depleted komatiites. Despite their having formed through low degrees of partial melting, it appears that little to no sulfide was retained in the residue. Sisson (2003) attributed the high Au content in a Hawaiian alkaline magma to high $f \mathrm{O}_{2}$ conditions in the mantle source region, conditions that destabilized sulfide and caused it to dissolve in the melt at low degrees of melting. The high alkalinity of the magma may also have contributed to the elimination of sulfide (Carroll and Webster, 1994). If these ideas are correct, they imply that a) the sources of alkali picrites and meimechites were relatively oxidized and b) sulfide was rare to absent even at the extremely low degrees of melting that produced meimechites.

\section{Passage from mantle to crust - influence of magma dynamics, tectonic setting, and crustal structure}

A magma that is strongly undersaturated in sulfide will crystallize large amounts of silicate minerals before an immiscible sulfide liquid begins to exsolve. Unless the sulfide melt separates physically from the crystals because of differences in density, solidification temperature, or other physical-chemical parameters, the product is a rock containing a small fraction of sulfide (typically 1-2 percent) disseminated between silicate minerals (e.g., Duke, 1986). Except when the metal contents of the metal-bearing phases are upgraded by fluid transfer or metamorphic processes, as appears to have been the case in some Type II deposits (Table 1) (e.g., Eckstrand, 1975; Donaldson, 1981), such rocks are not normally economic.

Normal fractional crystallization produces thin stratiform chromite- or PGE-rich horizons in differentiated mafic-ultramafic intrusions. However, this process forms economic deposits only in very large intrusions (e.g., Bushveld, Stillwater) where mixing of magmas with different compositions and/or mixing of magmas with late-stage, metal-rich silicate melts or aqueous fluids has concentrated ore minerals at specific stratigraphic levels, forming Type III deposits (Table 1), or in cross-cutting pipes or irregular zones.

For a Type I deposit to form, the sulfide liquid must separate early, before the crystallization of abundant silicate minerals. Sulfide deposits are relatively common in komatiites partly because the temperature difference between the liquidus and solidus is very large, as much as $400^{\circ} \mathrm{C}$. If sulfide segregates at temperatures even 100 to $200^{\circ} \mathrm{C}$ below the liquidus, it co-exists with few olivine crystals and can segregate and concentrate efficiently. In picritic or basaltic magmas the difference between the liquidus and solidus is smaller, as little as $50^{\circ} \mathrm{C}$. If sulfide is to accumulate separately from silicate minerals during the crystallization of picritic or basaltic magmas, either the normal crystallization sequence must be perturbed so that sulfide segregates much earlier, or other processes must concentrate the sulfide.

One process that perturbs the system is the assimilation of material from the continental crust into the magma. Exactly how this happens is poorly understood. Blocks of solid crust may totally melt and mix into the magma, partial melts of crustal rocks may be assimilated into the magma, volatile or fluid-soluble components may be transferred from wall rock to magma, or fragments of crustal rock may be incorporated into the magma as xenoliths or xenomelts (see discussion by Lesher and Burnham, 2001). The interaction between magma and crust has several 
consequences. The cooling of the magma that accompanies the assimilation of wall rocks may cause a sulfide liquid to segregate, and this may lead to the formation of sulfide deposits from magmas that are not strongly S-undersaturated. However, as noted above, magmas like komatiites, which are derived by melting deep in the mantle, are strongly undersaturated in sulfide, and even very large amounts of cooling and contamination may not drive them to saturation (Lesher and Arndt, 1995). Furthermore, the amount of S that can dissolve, even in mafic and ultramafic magmas, is small and it is extremely difficult to quantitatively extract appreciable amounts of sulfide without causing significant crystallization. Early segregation of sulfide liquid can result from assimilation of felsic rock such as granite or detrital sediment, which add Si and alkalis to produce a hybrid magma in which the sulfur solubility is lower (e.g., MacLean, 1969). However, the most efficient and most direct way of inducing sulfide saturation in sulfide-undersaturated magmas is by adding S. By assimilating sulfide or sulfate-bearing sedimentary or volcanic rocks, the $\mathrm{S}$ contents of the magma can be driven from levels well below sulfide saturation to the levels at which sulfide segregates (Gorbatchev and Grinenko, 1973; Green and Naldrett, 1981; Lesher et al., 1984; Grinenko 1985; Ripley, 1986; Lightfoot et al., 1994; Naldrett, 1992, 1996, 1999; Naldrett et al., 1992, 1996; Lightfoot and Hawkesworth, 1996).

The extent of interaction between magma and crust depends in part on the structure and petrological makeup of the crust and in part on the physical and dynamic characteristics of the magmas themselves. Important parameters include the densities and melting temperatures of the crustal rocks, and the presence of faults, zones of weakness in sedimentary strata and other structures that facilitate access to the surface. The state of stress in the crust and the deformation regime during magmatism will also influence the rate of magma ascent and interactions between magmas and crustal rocks. For this discussion, however, we will ignore these aspects and concentrate instead on the characteristics of the magmas themselves.

As discussed by Lesher et al. (2001), the amount of contamination depends on numerous factors, the most important being the composition, temperature and flow rate of the magma and the composition, physical characteristics and structure of the wall rocks. Other factors that have some influence are the $S$ and metal content of the contaminant, and the initial sulfide saturation state of the magma. The latter factors influence the assimilation/crystallization ratio, and the effective magma/sulfide ratio ( $\mathrm{R}$ factor) of the system. Because these processes vary independently from deposit to deposit, from area to area within a deposit, and within a single area with time, there are many opportunities to decouple contamination from chalcophileelement depletion.

There are three situations in which magma can assimilate a high proportion of crustal rock. The first is when the magma is superheated, for example as a result of rapid (adiabatic) ascent. The second is in a crustal magma chamber when the magma remains in a liquid state and stays in contact with wall rocks for a considerable period of time. The third is when turbulently flowing magma thermally erodes and assimilates its conduit walls or floor rocks.

In this context the following physical parameters of the magma are particularly important:

- Density: Magma chambers commonly form at levels in the lithosphere where the rock density drops sharply, such as at the crust-mantle boundary, at the limit between upper and lower crust, at the base of a sedimentary sequence, or at shallow levels in the crust where open fractures become abundant. At these levels, the density of mafic or ultramafic magma 
may exceed that of the overlying crustal rocks. The magma becomes trapped and differentiates in place to produce evolved and less dense liquids, which may continue their passage towards the surface.

- Viscosity: Low viscosity magmas flow rapidly and if the conduit or thickness of the lava flow is sufficiently large, the flow regime will be turbulent. Under these conditions the magma thermally erodes and rapidly assimilates its wall rocks (Huppert and Sparks, 1985).

- Temperature: High temperatures enhance the extent of crustal interaction in two ways: 1) high-temperature magmas have low viscosities, which may cause them to flow more rapidly and turbulently, and 2) high-temperature magmas are more capable of melting or reacting with their wall rocks.

- Magma flux: If the magma flux is high enough to cause turbulent flow, thermal erosion will result in rapid assimilation of wall rocks. At very high flow rates the contaminants may be diluted, but at moderate flow rates the amount of contamination can be up to $\sim 30$ percent for a basaltic magma and up to $\sim 50$ percent for a komatiitic magma (see discussion by Lesher and Arndt, 1995). If the flux is high, but insufficient to cause turbulent flow, there will be minimal assimilation of wall rocks because the magma will spend relatively little time in contact with fusible rocks. If the flux is still lower and if the magma accumulates in large magma chambers and interacts with wall or roof rocks, there is an opportunity for massive assimilation of wall rocks.

\section{A case study: the Noril'sk-Talnakh deposits}

Ongoing investigations of the Ni-Cu-PGE sulfide deposits of the Noril'sk-Talnakh mining region (e.g., Naldrett, 1989a,b; Naldrett et al., 1992; Lightfoot et al., 1994; Czamanske et al., 1994, 1995; Czamanske, 2002) have revealed a complex history of interaction between mantle-derived magma and crustal rocks. Various types of magma were involved, some of which assimilated significant amounts of crustal rocks, and others of which passed largely uncontaminated to the surface. Different types of crustal rocks were encountered, old granitoid crust at mid-crustal levels and young sedimentary rocks at shallower levels, but only one combination of magma type and crustal assimilant appears to have led to ore formation.

In the Nadezhdinsky basalts and in the lower, weakly mineralized intrusions, units considered to have predated emplacement of the ore-bearing intrusions, high $\mathrm{Th} / \mathrm{Nb}$ and $\square_{\mathrm{s}}$, and low $\square_{\mathrm{Nd}}$ correlate directly with depletions in chalcophile elements (Naldrett et al., 1992; Lightfoot et al., 1997; Arndt et al., 2003). The former parameters are sensitive indicators of the assimilation of old granitoid crust (or sedimentary rock derived from old granitic crust) and the latter is a sensitive indicator of sulfide segregation. It is generally accepted (e.g., Lightfoot et al., 1990; Naldrett, 1992, 2004; Brügmann et al., 1993; Czamanske et al., 1994) that these magmas interacted with granitoid crustal rocks or sedimentary rock, possibly in a mid-crustal magma chamber, and that this interaction led to the segregation of large amounts of sulfide (Fig. 6). However, if the magma had become strongly contaminated at depth and if this contamination had led to the segregation of sulfide and significant depletion of chalcophile elements, the sulfide that formed at this stage should have low metal tenors and high $\square_{s}$. Most Noril'sk ores, however, have moderately to extremely high chalcophile-element contents (Naldrett et al., 1992, 1996) and low, mantle-like $\bigsqcup_{\mathrm{s}}$ (Walker et al.1994; Arndt et al., 2003). If the ores had indeed 
resulted from granitoid contamination in deep crustal chambers, their metal tenors must subsequently have been upgraded and their Os isotopic compositions must have changed through interaction with additional magma (see discussion by Lesher and Burnham, 2001). Furthermore, the sulfur in the ore deposits is isotopically heavy $\left(9-13 \square^{34} \mathrm{~S}\right.$ : Grinenko, 1985; Ripley et al., 2003), a characteristic that is normally attributed to assimilation of anhydrite-bearing sedimentary country rocks (Naldrett et al., 1996; Lightfoot and Hawkesworth, 1997). Thus, the formation of the ore deposits appears to have been caused by interaction between magma and sedimentary rocks at relatively shallow levels and not by the assimilation of granitoid rocks at deeper crustal levels. As discussed by Arndt et al. (2003), it is possible that the sulfide that had segregated from the Nadezhdinsky basalts remained where it formed in the deep magma chamber and does not constitute a significant component of the ore deposits.

The Gudchikhinsky and Tuklonsky Suites of the flood-volcanic sequence contain dissimilar picritic flows and underlie the Nadezhdinsky basalts; all three suites are cut by the Noril'sk I intrusion and thus predate emplacement of the ore-bearing intrusions. The tholeiitic Tuklonsky picrites have petrological and geochemical characteristics that indicate that they formed from the same magma series as the intrusions that contain the sulfide ores (Wooden et al., 1993; Lightfoot et al., 1994; Naldrett, 2004). In contrast, the alkaline Gudchikhinsky picrites, which directly underlie the Tuklonsky picrites in the volcanic succession, appear to have played no role whatsoever in the ore-forming process. The two types of picrite have similar major-element compositions (apart from higher levels of alkalis and $\mathrm{TiO}_{2}$ in Gudchikhinsky samples: Table 4; Naldrett et al., 1992; Wooden et al., 1993; Lightfoot et al., 1994), yet only the magmas parental to the Tuklonsky picrites seem to have been capable of assimilating crustal material. Even though the Gudchikhinsky magmas were intruded into the same segment of continental crust and passed through the same sedimentary sequence as the tholeiitic Tuklonsky magmas, the isotopic and trace-element characteristics of the Gudchikhinsky picrites indicate that they assimilated negligible amounts of crust rock. Why is this so?

Some clues come from the volcanic sequence in the Maymecha-Kotuy region in the northeastern part of the volcanic province. In this region, alkaline lavas with compositions ranging from trachyte through picrite to meimechite (Vasil'yev and Zolotukhin, 1975; Fedorenko and Czamanske, 1997) overlie a series of tholeiitic basalts with geochemical characteristics similar to those in the Noril'sk-Talnakh region. At the interface between the two series, tholeiitic lavas alternate with alkaline lavas, indicating that the two magma types erupted synchronously. Arndt et al. (1998) have argued that the two types behaved very differently during their passage through the crust. The tholeiites have relatively constant, highly evolved compositions (Fig. 7) that are thought to represent steady-state liquids that accumulated, fractionated, became contaminated, and homogenized in large magma chambers (Wooden et al., 1993). The alkaline magmas, in contrast, exhibit a wide range of compositions, from highly magnesian meimechite to evolved trachyte and trachyrhyodacite, and show little sign of contamination. The alkaline magmas are interpreted to have fractionally crystallized as they migrated towards the surface, but to have interacted minimally with crustal rocks. The explanation proposed by Arndt et al. (1998) is that the alkaline magmas, being low-degree melts of a probably enriched mantle source, contained significant concentrations of $\mathrm{H}_{2} \mathrm{O}$ and $\mathrm{CO}_{2}$. The presence of these components is manifested mineralogically by the presence of phlogopite and magmatic amphibole in the groundmass of the lavas and by a regional association with carbonatites (Fedorenko and Czamanske, 1997). The presence of $\mathrm{H}_{2} \mathrm{O}$ and $\mathrm{CO}_{2}$ strongly reduces magma density (e.g., 
Anderson, 1995) and the relatively buoyant alkaline magma apparently bypassed the density discontinuities that trapped the tholeiitic magmas. Instead, they ascended rapidly to the surface with little interaction with crustal wall rocks.

If this explanation is correct, it provides an explanation for the apparent absence of Ni-Cu-(PGE) deposits in alkaline magmatic rocks. The answer is not related to the concentrations of ore metals or sulfur in the primary magmas. Rather, the high volatile content of these low-degree, partial melts caused them to pass rapidly through the crust without assimilating of crustal rocks, the process that appears to be crucial in the formation of magmatic sulfide deposits. Many such magmas erupt rapidly at the surface, without forming magma chambers. In others, degassing due to pressure release may have led to partial crystallization and the formation of viscous porphyritic magmas that stalled in magma chambers. However, the high viscosity and low temperature of these crystal-charged magmas would have inhibited assimilation of wall rocks and the high phenocryst content would have prevented efficient segregation of sulfide. On the other hand, the release of fluids from such magmas may give rise to hydrothermal precious-metal deposits (Richards, 1995).

\section{Formation of a Sulfide Ore Deposit}

In this section, we focus on how the interaction between magma and its host rocks forms a Fe$\mathrm{Ni}-\mathrm{Cu}$-(PGE) sulfide ore body. We accept that in many cases the segregation of sulfide is triggered or at least facilitated by the addition of $\mathrm{S}$ from an external source and we consider the following facets of the problem.

\section{Transfer of sulfur from source to magma}

When a link between crustal assimilation and sulfide segregation was first invoked (Naldrett, 1966; Prider, 1970) it was assumed that the $S$ was volatilized from S-rich country rocks. Subsequently, it has been recognized that there are several ways of transferring $S$ from wall rocks to form magmatic sulfide (see discussion by Lesher and Burnham, 2001). At one end of the spectrum is complete dissolution of all available $S$, which may occur if the magma is hot enough, if it is sufficiently undersaturated in sulfide, and if the $\mathrm{S}$ content of the assimilant is not too high. In intermediate cases, wholesale melting, incongruent melting, or devolatilization from the wall rocks, with or without other volatile and low-melting components, extracts part or all of the S. At the other end of the spectrum, sulfide is extracted from the wall rocks to form blobs of "xenomelt" that mingle with, but never dissolve in the silicate magma. This may happen if the magma is hot enough to melt the sulfide, but is already saturated in sulfide. All of these processes appear to have operated to different degrees in different deposits (see discussion by Lesher et al., 2001).

When the assimilated sulfur is in a reduced form, as sedimentary sulfide or $\mathrm{H}_{2} \mathrm{~S}$, the conversion to magmatic sulfide is direct, but when when the external sulfur is in the form of sulfate, it must be reduced before sulfides can form. Naldrett (2004) has suggested that in the Noril'sk-Talnakh region, where $\mathrm{S}$ isotopes provide strong evidence of anhydrite assimilation, coal from the terrigenous sedimentary rocks of the Tungusskaya formation may have acted as a reductant. However, he recognizes (A.J. Naldrett, pers. comm., 2004) the problem posed by the ore-bearing Kharaelakh intrusion, which is located stratigraphically below the Tungusskaya sedimentary rocks and which could not have interacted with coal-bearing strata. A possible solution lies in the nature of the older sedimentary units through which the magmas must have passed before 
reaching the ore-forming horizons. These units, Devonian marine to continental carbonates, marls, anhydrites and minor sandstone, correlate with the source rocks of the major oil and gas fields of the west Siberian basin (Clark et al., 1978). Bituminous shales of the upper Devonian Domanik Formation contain 1 to 5 percent organic matter. We are not aware of geochemical data from the sedimentary rocks in the Noril'sk-Talnakh region, but if they contained similar amounts of organic matter, their assimilation along with sulfate-bearing evaporites may have provided a mixture that led to the segregation of the ore sulfides.

The nature of dissolved sulfur may contribute to the lack of $\mathrm{Ni-Cu}$-(PGE) sulfide deposits associated with alkaline magmas. If these magmas formed from a relatively oxidized source, as suggested in the section on mantle melting, the sulfur will be present in the form of sulfate. For this sulfur to segregate as sulfide, it must first be reduced: the simple addition of granitic material, or a temperature decrease accompanied by crystallization, which may lead to sulfide segregation in more reduced magmas, will not suffice.

\section{Timing of sulfide saturation}

In most systems the sulfide phase is molten during all but the final stages of crystallization of the silicate minerals (see reviews by Naldrett, 1989, 2004). The sulfide and platinum-group minerals in these deposits represent low-temperature recrystallization and exsolution products of higher temperature phases, such Fe-Ni-rich monosulfide solid solution or $\mathrm{Cu}-\mathrm{Fe}$ rich intermediate solid solution.

Type I basal sulfides (Table 1) are segregated at or near the bases of the host units, indicating that sulfide saturation and segregation occurred early in their crystallization history (Lesher and Keays, 2002). The absence of widespread PGE depletion in most of the host rocks (e.g., Keays, 1982; Lesher and Groves, 1986; Lesher and Stone, 1996; Lesher et al., 2001) indicates that the sulfide could not have been transported directly from the mantle nor separated during ascent or in a subvolcanic magma chamber. The presence of local contamination and local PGE depletion in many of the host units (see Lesher et al., 2001; Li et al., 2003) indicates that the mineralization in many Type I deposits formed during eruption and emplacement. Because the solubility of sulfide in mafic-ultramafic magmas is low (1000-3000 ppm: see review by Naldrett, 2004), the large masses of sulfide in these deposits could not have completely dissolved in the available, relatively small volumes of magma represented by the host flows or intrusions. Instead, 1) sulfide segregated from much larger volumes of magma that flowed through and out of the host intrusion, 2) sulfur was added from an external source, and/or 3) sulfide melt was emplaced separately.

Type II strata-bound internal sulfides occur in the central parts of the host units, which, together with the presence of multiple ore horizons in some deposits (e.g., Katinniq: Gillies, 1993), indicates that sulfide saturation occurred during crystallization of the host rocks (Duke, 1986; Lesher and Keays, 2002). Type IIa blebby disseminated sulfides are too coarse (ave. $\sim 1 \mathrm{~cm}$ diameter, locally up to $5 \mathrm{~cm}$ ) to remain suspended in the magma except during rapid vertical flow and too abundant (up to 30 percent sulfide) to have dissolved in the magma and exsolved in situ, so their formation may have involved some type of in situ accumulation process as magma flowed through the host intrusion, which is consistent with their relatively uniform sizes and distributions in the cumulate host rock (Lesher and Groves, 1986; Lesher and Keays, 2002). 
Type IIb interstitial disseminated sulfides are also too abundant (1-3 percent) to have been dissolved in the small amount of interstitial liquid, indicating that these sulfides also segregated during olivine crystallization and accumulation. Duke (1986) suggested that magma in the Dumont intrusion became saturated in $\mathrm{S}$ when fractionated, S-enriched intercumulus liquid was expelled upward by filter-pressing of partially molten underlying cumulates and mixed with less evolved liquid at the temporary floor of the magma chamber. In this model the proportions of olivine and sulfide that separate from the melt are constrained by the abundance and solubility of sulfide in the melt and there is a limit to the amount of sulfide that may precipitate (Duke, 1986). However, as discussed by Lesher and Keays (2002), there is no simple relation between olivine accumulation and the degree of mineralization in many deposits (e.g., Katinniq: Gillies, 1993), and mass balance calculations and $\mathrm{S} / \mathrm{Se}$ data indicate that some external $\mathrm{S}$ is required (Lesher and Keays, 2002). Type IIc (cloud disseminated) sulfides are present in amounts that are small enough $(<1$ percent) to have dissolved in the interstitial silicate liquid (Lesher and Keays, 2002), but they are also commonly metal-poor, suggesting that they formed at very low R factors (e.g., Perseverance: Barnes et al., 1995) and/or represent sulfidated magnetite (e.g., Katinniq: Gillies, 1993). The origin of Type IId sulfides is not well understood.

Type III stratiform massive-dissemination occurs at specific stratigraphic intervals in the central parts of the host units, indicating that ore formation occurred during crystallization of the host rocks (Lesher and Keays, 2002). Although thin stratiform chromitite and PGE-rich sulfide horizons may form as a consequence of normal fractional crystallization processes (see Lesher and Stone, 1996; Lesher and Keays, 2002), almost all are sub-economic and other processes are obviously required to form ore deposits. There is still considerable debate as to whether the formation of stratiform PGE deposits was induced by magma mixing (e.g., Campbell et al., 1983), wall rock contamination (Maier et al. 2000), or filter pressing of interstitial melts and/or volatiles (Boudreau et al., 1986).

\section{Transport, upgrading, and accumulation of sulfide}

Campbell and Naldrett (1979), Naldrett (1989a), and Naldrett et al. (1992) have pointed out that the Ni, Cu and PGE contents of many ores are much higher than would be expected of sulfide that had separated from the quantity of magma represented by their relatively small host intrusions. The sulfide must have interacted with, and extracted ore metals from, a much larger volume of silicate liquid. This upgrading appears to have taken place within the lava channels and magma conduits that solidified to form the flows and intrusions that now host the ore bodies (e.g., Lesher and Campbell, 1993; Hawkesworth et al., 1995; Naldrett et al., 1992, 1996; Naldrett, 1999; Lightfoot et al., 1997; Ripley et al., 2003). New pulses of magma apparently flowed through the channels or conduits, interacting with pools of sulfide that had accumulated earlier and transferring chalcophile elements from the magmas to this sulfide.

Exactly how the magma interacts with sulfide is not clear and probably varies from deposit to deposit. What is critical is the manner in which sulfide is transported from where it formed to where it was deposited. Lava or magma surging through channels or conduits could have interacted with large amounts of S-bearing rocks (e.g., sulfidic sediments at Kambalda, evaporites at Noril'sk) either far upstream or at deeper levels in the sedimentary pile. Lesher and Groves (1986) and de Bremond d'Ars et al. (2001) have shown that droplets of dense sulfide as large as $1 \mathrm{~cm}$ (the size of droplets observed in many magmatic ore deposits) can be transported 
upwards in magma flowing rapidly through vertical conduits. Droplets have a large surface area/volume ratio and will effectively scavenge chalcophile elements as they are transported by the flowing lava or magma. If the average size of the droplets is large or if the discharge rate is low, the droplets will settle and collect at the base of the lava flow or magma conduit. The magma may continue to flow, but because a sulfide layer has a low surface area/volume ratio, it will not efficiently extract chalcophile elements from the overlying silicate liquid. Thus, the effective magma/sulfide ratio ( $\mathrm{R}$ factor) and therefore the tenors of sulfide ores are probably imposed during the initial stages of emplacement, when sulfide is most likely to be in suspension and to mix effectively with the silicate magma (Lesher and Campbell, 1993).

Authors working on the Jinchuan deposit in China (Tang, 1995), the Aguablanca deposit in Spain (Tornos et al., 2001), the Vammala deposit in Finland (Papunen and Vorma, 1985), and the Noril'sk (Kunilov, 1994; Stekhin, 1994) and Voisey's Bay (Li and Naldrett, 1999) deposits have noted that the massive ores or ore-breccias in these deposits locally transgress their host rocks. They suggest that these ores were injected, as separate pulses of massive liquid sulfide or as sulfide-rich breccias, into their positions at or near the bases of the host intrusions. Supporting evidence at Noril'sk is the scarcity of transitions from disseminated to massive ores (Zen'ko and Czamanske, 1994; Czamanske et al., 1995). It is not clear, however, how dense, low viscosity sulfide liquid can be extracted from sites of accumulation and transported upwards through much less dense crustal rocks. Commonly invoked ideas include deformation along a major fault, or collapse of the roof of a magmatic body differentiating at depth, processes that physically expel mixtures of silicate liquid, cumulus minerals, fragments of wall rocks, and accumulated sulfide liquids. Alternatively, the transgressive relations may have simply been produced by mobilization of still-molten sulfide melts during structural readjustments around the host intrusions.

\section{The influence of magma composition, revisited}

Let us now reconsider the influence of the parental magma composition. At Noril'sk there is clear evidence that only one particular type of magma, probably of tholeiitic picritic composition related to the basaltic lavas midway in the volcanic pile, was parental to the ore deposits. This could be coincidence; the association of this magma with the ore deposits may relate entirely to physical factors that influenced interactions with the S-rich evaporitic country rocks. Nonetheless, two features suggest that this magma, and not an alkali picrite, formed the sulfide ores. 1) The tholeiitic picrite had high contents of $\mathrm{Cu}$ and PPGE, which allowed it to produce higher tenors of those elements, and a low volatile content, which allowed it to interact more effectively with evaporitic country rocks. 2) The magma appears to have followed a specific path to the surface that enabled it to bypass the intermediate-level magma chambers that trapped the magmas parental to the Nadezhdinsky basalts. Instead of interacting with granitic crust and precipitating sulfide at a deep, inaccessible level, the magma that formed the ore deposits was relatively uncontaminated (and therefore hotter and less viscous than the Nadezhdinsky-type magmas) when it reached the sedimentary pile. It then interacted with evaporites and segregated sulfide at shallow, mineable levels. The volatile-rich, low-density alkali picritic magma, in contrast, passed rapidly to the surface, interacting little with crustal rocks and thus reducing any opportunity to form sulfide ores.

Alkaline and tholeiitic basalts and picrites are present in many other flood volcanic provinces. In the Ethiopian province, only a small proportion of the basalts have tholeiitic characteristics (Pik 
et al., 1998, 1999; Kieffer et al., 2004). The picrites are strongly enriched in alkali and highly incompatible elements and resemble the Gudchikhinsky picrites and meimechites of the Siberian province (Figs. 2 and 5). These magmas are not prospective hosts to $\mathrm{Fe}-\mathrm{Ni}-\mathrm{Cu}-(\mathrm{PGE})$ sulfide mineralization. Published analyses of basalts from the Emeishan province in southeast China (e.g., Song et al., 2003) also reveal an alkali character. This may be part of the reason why no large, massive sulfide deposits have been found in this province. In the case of other flood volcanic provinces, such as Deccan, Karoo, and Greenland, most of the magmas are tholeiitic, and picrites as well as S-bearing sedimentary rocks, are present as well. In these cases, the apparent absence of $\mathrm{Ni}-\mathrm{Cu}-(\mathrm{PGE})$ deposits may be related to vagaries in the magmatic plumbing system that prevented interaction between primitive metal-rich magma and S-rich sediments. In Greenland, there is clear geological and geochemical evidence that the magmas assimilated continental crust, in some cases accompanied by the segregation of sulfide (Lightfoot and Hawkesworth, 1997). However, this interaction may have taken place at deep inaccessible levels, as seems to have happened during the emplacement of the Nadezhdinsky basalts in the Noril'sk region.

The parental magma of the Voisey's Bay Ni-Cu sulfide deposit was unusually rich in $\mathrm{Al}$ and crystallized a variety of gabbroic and troctolitic rocks (Li and Naldrett 1999; Scoates and Mitchell, 2001). They are related magmatically to anorthositic complexes and their origin is not clear. The primary magma, probably picritic, formed by partial melting of mantle beneath thick Archean lithosphere and interacted with crustal rocks before reaching the level of the ore deposits. Li and Naldrett (1999) concluded that at least two pulses of magma were involved in formation of the ore deposit. They suggested that an initial pulse of magma entered a lower chamber and became saturated in sulfide as crystallization proceeded, as a result of the assimilation of S-bearing gneissic roof rocks (Ripley et al., 1999). Some of this $\mathrm{Ni}$ - and $\mathrm{Cu}-$ enriched sulfide remained in the lower chamber and some was swept up with the advancing magma and became concentrated in the $\sim 1 \mathrm{~km}$-long conduit leading to the upper chamber. The second pulse of magma was less fractionated than the residual magma in the lower chamber and retained most of its chalcophile-element content. Interaction with this magma further enriched earlier-formed sulfide in $\mathrm{Ni}$ and $\mathrm{Cu}$, as residual initial magma, sulfide, and gneiss inclusions were forced upward. Complexities in the plumbing system appear to have resulted in both turbulent and laminar flow, as well as magma mixing, as evidenced by variations in olivine compositions and in whole rock $\mathrm{Cu} / \mathrm{Zr}$ ratios ( $\mathrm{Li}$ and Naldrett, 1999).

The parent magma of the Bushveld Complex and Stillwater Complexes has been interpreted as boninitic (Hatton and Sharpe, 1988), as a partial melt of sub-continental lithospheric mantle (Hamlyn et al., 1986; Lambert and Simmons, 1987), or as a crustally-contaminated komatiite (Irvine, 1977; Barnes, 1989; Maier et al., 2000). We believe that the first possibility can be dismissed, partly from a lack of evidence of subduction at the time of Bushveld emplacement, but more convincingly from the trace element and isotopic compositions of Bushveld rocks (Kruger, 1994; Maier et al., 2000). The initial $[N d$ values of these rocks are extremely negative, ranging from about -6 to -8 . Such values are unknown in rocks from modern subduction zones (boninites commonly have distinctly positive values: Crawford, 1988) and are even more unlikely in the Early Proterozoic, when subducted terrigeneous sediments would have had less extreme $\mathrm{Nd}$ isotopic compositions than modern sediments. The trace element and $\mathrm{Sr}, \mathrm{Nd}$, and $\mathrm{Os}$ isotopic compositions of Bushveld rocks are far more consistent with high degrees of contamination with granitoid crustal rocks. 
The PGE contents estimated for the magmas that fed into the Bushveld chamber are high (Davies and Tredoux, 1985), indicating that these magmas never segregated sulfide. It is possible that the primary Bushveld magmas were komatiites that had formed by melting at extreme mantle depths, like the komatiites of the Barberton belt, and had reached crustal levels in a highly Sundersaturated state. Under these conditions, the magma could assimilate a large amount of crust and crystallize considerable olivine \pm orthopyroxene, without becoming saturated with sulfur. Comparison can be made with siliceous high-Mg basalts in the volcanic pile above the Kambalda ore bodies. According to Arndt and Jenner (1986) and Lesher and Arndt (1995), the parental komatiitic magmas assimilated up to 30 percent older granitic crustal rocks, yet their PGE contents remained relatively high. As seen in Fig. 8, the PGE contents of Kambalda high-Mg basalts are very similar to those of the marginal sills that commonly are taken to represent the parental magma of the Bushveld Complex. It appears that only when the Bushveld magma assimilated sedimentary rocks, as at the Platreef deposit, did it precipitate large amounts of PGErich sulfides. In the main body of the chamber, S-rich wall rocks were never encountered and only minor amounts of sulfide formed. However, because this happened within the vast Bushveld magma chamber, or in an equally vast staging chamber (Maier et al., 2000), this sparse sulfide was able to interact with a large volume of silicate magma (Campbell et al., 1983), to produce the rich PGE deposits for which the Bushveld Complex is famous.

\section{Conclusions}

The capacity of a magma to form a Ni-Cu-(PGE) deposit depends primarily on its ability to interact with crustal wall rocks and only to a minor extent on its $\mathrm{Ni}, \mathrm{Cu}$, and PGE contents. Komatiitic, tholeiitic, and alkaline mafic and ultramafic magmas have sufficiently high metal contents, but only the former are known to host magmatic sulfide deposits.

The absence of primary $\mathrm{Ni}-\mathrm{Cu}-(\mathrm{PGE})$ deposits in alkali picrites and meimechites results from the manner in which these magmas traversed the continental crust. These volatile-rich magmas had low densities, such that they were not trapped at density discontinuities, and may have ascended rapidly; they therefore had little opportunity to interact with crustal rocks. In contrast, volatilepoor and dense tholeiitic magmas passed through a series of crustal magma chambers in which they assimilated crustal wall rocks.

The cooling and contamination of slightly S-undersaturated magmas in deep crustal chambers may have caused the segregation of sulfide liquids, but in certain cases these liquids remained at deep, normally inaccessible levels. The best ore deposits form when more highly Sundersaturated magmas assimilate S-bearing wall rocks in the upper parts of volcanosedimentary basins.

The unique character of the Noril'sk-Talnakh magmas resulted from the interaction of a specific magma type with an unusual suite of sedimentary rocks. The magma was a picrite that had largely escaped granitic contamination in deep crustal chambers and retained a full complement of ore metals; the sediments that this magma assimilated comprised anhydrite-bearing evaporites (the $\mathrm{S}$ source) and bituminous shales (a reductant). 


\section{Acknowledgements}

We have benefited greatly from discussions with numerous colleagues, including Chris Ballhaus, Sarah-Jane Barnes, Marcus Burnham, Ian Campbell, Paul Golightly, Pedro Jugo, Reid Keays, Peter Lightfoot, Tony Naldrett, and Igor Puchtel. Our research on magmatic ore deposits has been supported at various stages by the Groupement de Recherche de Métallogénie of the Centre National de Recherche Scientifique, the Canadian Mining Industry Research Organization, the Natural Sciences and Engineering Research Council of Canada, and the US National Science Foundation. Peter Lightfoot and Ed Ripley provided useful and constructive reviews. We are particularly grateful to Jeremy Richards for his constructive comments on the manuscript and patience during the revision process.

\section{References}

Anderson, A. T., 1995, $\mathrm{CO}_{2}$ and the eruptibility of picrite and komatiite: Lithos, v. 34, p. 19-26.

Arndt, N. T., 2003. Komatiites, kimberlites and boninites. Journal of Geophysical Research, v. 108, B6, 2293, doi:10.1029/2002JB002157.

Arndt, N. T., Chauvel, C., Fedorenko, V., and Czamanske, G., 1998, Two mantle sources, two plumbing systems: tholeiitic and alkaline magmatism of the Maymecha River basin, Siberian flood volcanic province: Contributions to Mineralogy and Petrology, v. 133, p. 297-313.

Arndt, N. T., Czamanske, G., Walker, R. J., Chauvel, C., and Fedorenko, V., 2003, Geochemistry and origin of the intrusive hosts of the Noril'sk-Talnakh Cu-Ni-PGE sulfide deposits: Economic Geology, v. 98, p. 495-515.

Arndt, N. T. and Jenner, G.A., 1986, Crustally contaminated komatiites and basalts from Kambalda, Western Australia: Chemical Geology, v. 56, p. 229-255.

Arndt, N. T., Lehnert, K., and Vasil'ev, Y., 1995, Meimechites: highly magnesian alkaline magmas from the subcontinental lithosphere?: Lithos, v. 34, p. 41-59.

Arndt, N. T. and Nesbitt, R., 1984, Magma mixing in komatiitic lavas from Munro Township, Ontario, in A. Kröner, G.N. Hanson and A.M. Goodwin, Eds., Archaean Geochemistry: Springer-Verlag, Berlin, p. 99-115.

Ballhaus, C., Ryan, C. G., Mernach, T. P., and Green, D. H., 1994, The partitioning of Fe, Ni, $\mathrm{Cu}, \mathrm{Pt}$ and $\mathrm{Au}$ between sulfide, metal, and fluid phases: a pilot study: Geochimica et Cosmochimica Acta, v. 58, p. 811-826.

Barnes, S. J., 1989, Are Bushveld magmas boninites or contaminated komatiites?: Contributions to Mineralogy and Petrology, v. 101, p. 447-457.

Barnes, S. J., Lesher, C. M., and Keays, R. R., 1995, Geochemistry of mineralised and barren komatiites from the Perseverance nickel deposit, Western Australia: Lithos, v. 34, p. 209234.

Barnes, S.-J., Naldrett, A. J., and Gorton, M. P., 1985, The origin of the fractionation of platinum-group elements in terrestrial magmas: Chemical Geology, v. 53, p. 303-323.

Bockrath, C., Ballhaus, C., and Holzheid, A., 2004a, Stabilities of laurite $\mathrm{RuS}_{2}$ and monosulfide liquid solution at magmatic temperature: Chemical Geology, v. 208, p. 265-271.

Bockrath, C., Holzheid, A., and Ballhaus, C., 2004b, Fractionation of the platinum-group elements during mantle melting: Science, v. 305. p. 1951-1953.

Brügmann, G. E., Arndt, N. T., Hofmann, A. W., and Tobschall, H. J., 1987, Noble metal abundances in komatiite suites from Alexo, Ontario, and Gorgona Island, Colombia: Geochimica et Cosmochimica Acta, v. 51, p. 2159-2170.

Brügmann, G. E., Naldrett, A. J., Asif, M., Lightfoot, P. C., Gorbachev, N. S., and Fedorenko, V. 
A., 1993, Siderophile and chalcophile metals as tracers of the evolution of the Siberian trap in the Noril'sk region, Russia: Geochimica et Cosmochimica Acta, v. 57, p. 2001-2018.

Campbell, I. H., and Naldrett, A. J., 1979, The influence of silicate:sulfide ratios on the geochemistry of magmatic sulfides: Economic Geology, v. 74, p. 1503-1505.

Campbell, I.H., Naldrett, A.J. and Barnes, S.J., 1983, A model for the origin of the platinum-rich sulphide horizons in the Bushveld and Stillwater Complexes: Journal of Petrology, v. 24, p. 133-165.

Carmichael, I.S.E., 1991, The redox states of basic and silicic magmas: a reflection of their source regions?: Contributions to Mineralogy and Petrology, v. 106, p. 129-141.

Carroll, M.R., and Webster, J.D., 1994, Solubilities of sulfur, noble gases, nitrogen, chlorine, and fluorine in magmas, in M.R. Carroll and J.R. Holloway, eds., Volatiles in Magmas: Reviews in Mineralogy, v. 30, p.231 -279.

Clarke, J. W., O. W. Girard, Jr., J. Peterson, and J. Rachlin, 1978. Petroleum geology of Western Siberian basin and Samotlor oil field: Oil and Gas Journal, v. 8, p.311-328.

Crawford, A. J., 1988, Boninites, London, Unwyn Hyman Ltd, p. 554.

Crocket, J. H., 1979, Platinum-group elements in mafic ultramafic rocks: a survey: Canadian Mineralogist, v. 17, p. 391-402.

Crocket, J.H., 2002, Platinum-group elements in basalts from Maui, Hawai'i: low abundances in alkali basalts: Canadian Mineralogist, v. 40, p. 585-610.

Czamanske, G. K., Wooden, J. L., Zientek, M. L., Fedorenko, V. A., Zen'ko, T. E., Kent, J., King, B. S., Knight, R. L., and Siems, D. F., 1994, Geochemical and isotopic constraints on the petrogenesis of the Noril'sk-Talnahk ore-forming system, in Lightfoot, P. C., and Naldrett, A. J., eds., Proceedings of the Sudbury-Noril'sk Symposium: Sudbury, Ontario Geological Survey, p. 313-342.

Czamanske, G. K., Zen'ko, T. E., Fedorenko, V. A., Calk, L. C., Budahn, J. R., Bullock, J. H., Jr., Fries, T. L., King, B. S., and Siems, D. F., 1995, Petrography and geochemical characterization of ore-bearing intrusions of the Noril'sk type, Siberia; with discussion of their origin.: Resource Geology Special Issue, v. 18, p. 1-48.

Czamanske, G.K., 2002, Petrographic and geochemical characterization of ore-bearing intrusions of the Noril'sk type, Siberia; with discussion of their origin and full datasets http://geopubs.wr.usgs.gov/open-file/of02-074

Davies, G., and Tredoux, M., 1985, The platinum-group element and gold contents of the marginal rocks and sills of the Bushveld Complex: Economic Geology, v. 80, p. 838-848.

de Bremond d'Ars, J., Arndt, N.T. Hallot, E., 2001, Analog experimental insights into the formation of magmatic sulfide deposits: Earth and Planetary Science Letters, v. 186, p. 371381.

Donaldson, M.J., 1981, Redistribution of ore elements during serpentinization and talc-carbonate alteration of some Archaean dunites, Western Australia: Economic Geology, v. 76, p. 16981713.

Duke, J.M., 1986, Petrology and economic geology of the Dumont sill: An Archean intrusion of komatiitic affinity in Northwestern Québec: Economic Geology Report 35, Geological Survey of Canada, Ottawa, $56 \mathrm{pp}$.

Eckstrand, O.R., 1975, The Dumont serpentinite: A model for control of nickeliferous opaque assemblages by alternation products in ultramafic rocks: Economic Geology, v. 70, p. 83-201.

Fedorenko, V., and Czamanske, G., 1997, Results of new field and geochemical studies of the volcanic and intrusive rocks of the Maymecha-Kotuy area, Siberian Flood-Basalt Province, 
Russia: International Geology Review, v. 39, p. 479-531.

Fleet, M. E., Tronnes, R. G., and Stone, W. E., 1996, Partitioning of platinum-group elements (Os, Ir, Ru, Pt, Pd) and gold between sulfide liquid and basalt melt: Geochimica et Cosmochimica Acta, v. 60, p. 2397-2412.

Gangopadhyay, A., and Walker, R. J., 2003, Re-Os systematics of the ca. 2.7 Ga komatiites from Alexo, Ontario, Canada: Chemical Geology, v. 196, p. 147-162.

Gibson, S. A., Thompson, R. N. and Dickin, A. P., 2000, Ferropicrites: geochemical evidence for Fe-rich streaks in upwelling mantle plumes: Earth and Planetary Science Letters, v. 174, p. 355-374.

Gillies, S. L., 1993, Physical Volcanology and Genesis of the Katinniq Peridotite Complex and Associated Fe-Ni-Cu Sulfide Mineralization, Cape Smith Belt, New Québec: Unpubl. M.Sc. thesis, University of Alabama, $146 \mathrm{pp}$.

Gorbachev, N. S., and Grinenko, L. N., 1973, The sulfur isotope ratios of the sulphides and sulphates of the Oktyabr'sk sulphide deposit, Noril'sk region, and the problem of its origin: Geokhimiya, v. 8, p. 1127-1136.

Green, A. H., and Naldrett, A. J., 1981, The Langmuir volcanic peridotite-associated nickel sulphide deposits: Canadian equivalents of the Western Australian occurrences: Economic Geology, v. 76, p. 1503-1523.

Grinenko, L. N., 1985, Sources of sulfur of the nickeliferous and barren gabbro-dolerite intrusions of the northwest Siberian platform: International Geology Review, v. 28, p. 695708.

Hamlyn, P. R., and Keays, R. R., 1986, Sulphur saturation and second-stage melts: application to the Bushveld platinum metal deposits: Economic Geology, v. 81, p. 1431-1445.

Hanski, E.J., 1992, Petrology of the Pechenga ferropicrites and cogenetic, Ni-bearing gabbrowehrlite intrusions, Kola Peninsula, Russia: Geological Survey of Finland, Espoo, 192 pp.

Hatton, C. J., and Sharpe, M. R., 1988, Significance and origin of boninite-like rocks associated with the Bushveld Complex: in Crawford, A. J., ed., Boninites, London, Unwyn Hyman Ltd, p. 174-207.

Harris, P.G., 1957, Zone refining and the origin of potassic basalts: Geochimica et Cosmochimica Acta, v. 12, p. 195-208.

Hawkesworth, C. J., Lightfoot, P. C., Fedorenko, V. A., Blake, S., Naldrett, A. J., Doherty, W., and Gorbachev, N. S., 1995, Magma differentiation and mineralisation in the Siberian flood basalts: Lithos, v. 34, p. 61-88.

Helz, R. T., 1977, Determination of the P-T dependence of the first appearance of FeS-rich liquid in natural basalts to $20 \mathrm{~kb}$ : EOS, Transactions, American Geophysical Union, v. 58, pp. 523.

Herzberg, C. T., and O'Hara, M. J., 1998, Phase equilibrium constraints of the origin of basalts, picrites, and komatiites: Earth Science Reviews, v. 44, p. 39-79.

Hofmann, A. W., 1989, Chemical differentiation of the Earth: the relationship between mantle, continental crust, and oceanic crust: Earth and Planetary Science Letters, v. 90, p. 297-314.

Hofmann, A. W., and White, W. M., 1982, Mantle plumes from ancient oceanic crust: Earth and Planetary Science Letters, v. 57, p. 421-436.

Holzheid, A., Sylvester, P., Palme, H., Borisov, A., and Rubie, D.C., 1998, Solubilities of Pt, Ir, and Pd in silicate melts at high pressures, Lunar Planetary Science Conference XXIX, Abstract \#1296.

Horan, M. F., Walker, R. J., Fedorenko, V. A., and Czamanske, G. K., 1995, Osmium and neodymium isotopic constraints on the temporal and spatial evolution of Siberian flood basalt 
sources: Geochimica et Cosmochimica Acta, v. 59, p. 5159-5168.

Huppert, H. E., and Sparks, R. S. J., 1985, Komatiites I: Eruption and flow: Journal of Petrology, v. 26, p. 694-725.

Irvine, T. N., 1977, Origin of chromite layers in the Muskox intrusion and other stratiform intrusions: a new interpretation: Geology, v. 5, p. 273-277.

Jochum, K. P., Arndt, N. T., and Hofmann, A. W., 1990, Nb-Th-La in komatiites and basalts: constraints on komatiite petrogenesis and mantle evolution: Earth and Planetary Science Letters, v. 107, p. 272-289.

Jugo, P.J., Luth, R.W., and Richards, J.P., 2005, An experimental study of the sulfur content in basaltic melts saturated with immiscible sulfide or sulfate liquids at $1300^{\circ} \mathrm{C}$ and $1.0 \mathrm{GPa}$ : Journal of Petrology, v. 46, p. 783-798.

Keays, R. R., 1982, Palladium and iridium in komatiites and associated rocks: Application to petrogenetic problems, in Arndt, N. T., and Nisbet, E. G., eds., Komatiites: London, George Allen and Unwin, p. 435-458.

Keays, R. R., 1995, The role of komatiite and picritic magmatism and S-saturation in the formation of ore deposits: Lithos, v. 34, p. 1-18.

Kieffer, B., Arndt, N. T., Lapierre, H., Bastien, F., Bosch, D., Pecher, A., Yirgu, G., Ayalew, D., Weis, D., Jerram, D., Keller, F., and Meugniot, C., 2004, Flood and shield basalts from Ethiopia: magmas from the African superswell: Journal of Petrology , v. 45, p. 793-834.

Kinzler, R. J., Grove, T. L., and Recca, S. I., 1990, An experimental study on the effect of temperature and melt composition on the partitioning of nickel between olivine and silicate melt: Geochimica et Cosmochimica Acta, v. 54, p. 1255-1265.

Kunilov, V. Y., 1994, Geology of the Noril'sk region: The history of the discovery, prospecting, exploration and mining of the Noril'sk deposits: Ontario Geological Survey Special Volume 5, p. 203-216.

Kruger, F. J., 1994, The Sr-isotopic stratigraphy of the western Bushveld Complex: South African Journal of Geology, v. 97, p. 393-398.

Lahaye, Y., Arndt, N. T., Byerly, G., Gruau, G., Fourcade, S., and Chauvel, C., 1995, The influence of alteration on the trace-element and $\mathrm{Nd}$ isotope compositions of komatiites: Chemical Geology, v. 126, p. 43-64.

Lambert, D.D. and Simmons, E.C., 1987, Magma evolution in the Stillwater Complex, Montana: I. Rare-earth element evidence for the formation of the Ultramafic Series: American Journal of Science, v. 287, p.1-32.

Langmuir, C., Klein, E. and Plank, T., 1992, Petrological systematics of mid-ocean ridge basalts: constraints on melt generation beneath ocean ridges, in Phipps Morgan, J., Blackman D. and Sinton, J., eds., Mantle flow and melt generation at mid-ocean ridges: Geophysical Monograph 71, American Geophysical Union , p. 183.

Lesher, C. M., 1989, Komatiite-associated nickel sulfide deposits, in Whitney, J. A., and Naldrett, A. J., eds., Ore deposition associated with magmas: Society of Economic Geologists, p. 45-102.

Lesher, C. M., and Arndt, N. T., 1995, REE and Nd isotope geochemistry, petrogenesis and volcanic evolution of contaminated komatiites at Kambalda, Western Australia: Lithos, v. 34, p. 127-158.

Lesher, C.M., and Burnham, O.M., 2001, Multicomponent elemental and isotopic mixing in Ni$\mathrm{Cu}-(\mathrm{PGE})$ ores at Kambalda, Western Australia: Canadian Mineralogist, v. 39, p. 421-446.

Lesher, C. M., and Groves, D. I., 1986, Controls on the formation of komatiite-associated nickel- 
copper sulfide deposits: in Friedrich, G. H., ed., Geology and Metallogeny of Copper Deposits, Berlin, Springer-Verlag, p. 43-62.

Lesher, C.M., and Keays, R.R., 2002, Komatiite-Associated Ni-Cu-(PGE) Deposits: Mineralogy, Geochemistry, and Genesis, in Cabri, L.J., ed., The Geology, Geochemistry, Mineralogy, and Mineral Beneficiation of the Platinum-Group Elements: Canadian Institute of Mining, Metallurgy and Petroleum, Special Volume 54, p. 579-617.

Lesher, C. M., and Stone, W. E., 1996, Exploration geochemistry of komatiites, in Wyman, D., ed., Igneous Trace Element Geochemistry: Applications for Massive Sulphide Exploration: Geological Society of Canada, Short Course Notes, p. 153-204.

Lesher, C. M., Burnham, O. M., Keays, R. R., Barnes, S. J., and Hulbert, L., 2001, Geochemical discrimination of barren and mineralized komatiites associated with magmatic Ni-Cu-(PGE) sulfide deposits: Canadian Mineralogist, v. 39, p. 673-696.

Lesher, C.M., and Campbell, I.H., 1993, Geochemical and fluid dynamic modeling of compositional variations in Archean komatiite-hosted nickel sulfide ores in Western Australia: Economic Geology, v. 88, p. 804-816.

Lesher, C.M., Arndt, N.T., and Groves, D.I., 1984, Genesis of komatiite-associated nickel sulphide deposits at Kambalda, Western Australia: A distal volcanic model, in Buchanan, D.L., and Jones, M.J., eds., Sulphide Deposits in Mafic and Ultramafic Rocks: Institution of Mining and Metallurgy, London, p. 70-80.

Li, C., and Naldrett, A. J., 1999, Geology and petrology of the Voisey's Bay intrusion: reaction of olivine with sulfide and silicate liquids: Lithos, v. 47, p. 1-31.

Li, C., and Ripley, E.M., in press, Empirical equations to predict the sulfur content of mafic magmas at sulfide saturation and applications to magmatic sulfide deposits, Economic Geology.

Li, C., Ripley, E. M., and Naldrett, A. J., 2003, Compositional variations of olivine and sulfur isotopes in the Noril'sk and Talnakh intrusions, Siberia: implications for ore forming processes in dynamic magma conduits: Economic Geology, v. 98, p. 69-86

Lightfoot, P. C., Naldrett, A. J., Gorbachev, N. S., and Fedorenko, V. A., 1990, Geochemistry of the Siberian trap of the Noril'sk area, USSR, with implications for the relative contributions of crust and mantle to flood basalt magmatism: Contributions to Mineralogy and Petrology, v. 104, p. 631-644.

Lightfoot, P. C., and Hawkesworth, C. J., 1997, Flood basalts and magmatic Ni, Cu, and PGE sulphide mineralization: comparative geochemistry of the Noril'sk (Siberian Traps) and West Greenland sequences, in Mahoney, J. J., and Coffin, M. F., eds., Large igneous provinces: continental, oceanic and planetary flood volcanism: American Geophysical Union, Monograph 100, p. 357-380.

Lightfoot, P. C., Naldrett, A. J., Gorbachev, N. S., Fedorenko, V. A., Hawkesworth, C. J., Hergt, J., and Doherty, W., 1994, Chemostratigraphy of Siberian Trap lavas, Noril'sk District, Russia: implications for the source of flood basalt magmas and their associated $\mathrm{Ni}-\mathrm{Cu}$ mineralization, in Naldrett, A. J., and Lightfoot, P. C., eds., Proceedings of the SudburyNoril'sk Symposium: Sudbury, Ontario Geological Survey, p. 283-312.

Maier, W. D., Arndt, N. T., and Curl, E. A., 2000, Progressive crustal contamination of the Bushveld Complex: evidence from $\mathrm{Nd}$ isotopic analyses of the cumulate rocks: Contributions to Mineralogy and Petrology, v. 140, p. 328-343.

Maier, W. D., Roelofse, F., and Barnes, S.-J., 2003, The concentrations of the platinum-groujp elements in South African komatiites: implications for mantle sources and melting regime: 
Journal of Petrology, v. 44, p. 1787-1804.

Mavrogenes, J. A., and O'Neil, H., 1999, The relative effects of pressure, temperature, and oxygen fugacity on the solubility of sulfide in mafic magmas: Geochimica et Cosmochimica Acta, v. 63, p. 1173-1180.

MacLean, W.H., 1969, Liquidus phase relations in the $\mathrm{FeS}-\mathrm{FeO}-\mathrm{Fe}_{2} \mathrm{O}_{3}-\mathrm{SiO}_{2}$ system and their application in geology: Economic Geology, v. 64, p. 865-884.

McDonough, W. F., and Sun, S.-S., 1995, The composition of the Earth: Chemical Geology, v. 120, p. 223-253.

Momme, P., Tegner, C., Brooks, C. K., and Keays, R. R., 2002, The behaviour of platinumgroup elements in basalts from the East Greenland rifted margin: Contributions to Mineralogy and Petrology, v. 143, p. 133-153.

Naldrett, A.J., 1966, The role of sulphurization in the genesis of iron-nickel sulphide deposits of the Porcupine District, Ontario, Canadian Institute of Mining and Metallurgy, Transactions, v. 69, p. 147-155.

Naldrett, A. J., 1989a, Introduction: magmatic deposits associated with mafic rocks, in Whitney, J. A., and Naldrett, A. J., eds., Ore deposition associated with magmas: Society of Economic Geologists, p. 1-3.

Naldrett, A. J., 1989b, Magmatic Sulfide Deposits: Oxford, Oxford University Press, 196 p.

Naldrett, A. J., 1992, A model for the Ni-Cu-PGE ores of the Noril'sk region and its application to other areas of flood basalt: Economic Geology, v. 87, p. 1945-1962.

Naldrett, A. J., 1999, World class Ni-Cu-PGE deposits: key factors in their genesis: Mineralium Deposita, v. 34, p. 227-240.

Naldrett, A. J., 2004, Magmatic Sulfide Deposits: Geology, Geochemistry, and Exploration, Springer, $727 \mathrm{pp}$.

Naldrett, A. J., and Barnes, S.-J., 1986, The behavior of platinum group elements during fractional crystallization and partial melting with special reference to the composition of magmatic sulfide ores: Forschritte der Mineralogie, v. 74, p. 113-133.

Naldrett, A. J., Fedorenko, V. A., Lightfoot, P. C., Kunilov, V. I., Gorbachev, N. S., Doherty, W., and Johan, Z., 1996, Controls on the composition of Ni-Cu sulfide deposits as illustrated by those at Noril'sk, Siberia: Economic Geology, v 91 p. 751-773.

Naldrett, A. J., Lightfoot, P. C., Fedorenko, V. A., Gorbachev, N. S., and Doherty, W., 1992, Geology and geochemistry of intrusions and flood basalts of the Noril'sk region, USSR, with implications for the origin of the Ni-Cu ores: Economic Geology, v. 87, p. 975-1004.

Navon, O., and Stolper, E., 1987, Geochemical consequences of melt percolation: the upper mantle as a chromatographic column: Journal of Geology, v. 95, p. 285-307.

O'Neill, H. S. C., Dingwell, D. B., Borisov, A., Spettel, B., and Palme, H., 1995, Experimental petrochemistry of some highly siderophile elements at high temperatures, and some implications for core formation and the mantle's early history: Chemical Geology, v. 120, p. 255-273.

Papunen, H., and Vorma, A., 1985, Nickel Deposits in Finland, a Review, in Papunen, H. and Gorbunov, G. I., Eds., Nickel-Copper Deposits of the Baltic Shield and Scandinavian Caledonides: Geological Survey of Finland, Bulletin 333, p. 123 - 139.

Peach, C. L., Mathez, E. A., Keays, R. R., and Reeves, S. J., 1994, Experimentally-determined sulfide melt-silicate melt partition coefficients for iridium and palladium: Chemical Geology, v. 117, p. 361-377.

Pik, R., Deniel, C., Coulon, C., Yirgu, G., and B., M., 1999, Isotopic and trace element 
signatures of Ethiopian Flood Basalts: Evidence for plume-lithosphere interactions:

Geochimica et Cosmochimica Acta., v. 63, p. 2263-2279.

Pik, R., Deniel, C., Coulon, C., Yirgu, G., Hofmann, C., and Ayalew, D., 1998, The

Northwestern Ethiopian plateau flood basalts: Classification and spatial distribution of magma types: Journal of Volcanology and Geothermal Research, v. 81, p. 91-111.

Prider, R. T., 1970, Nickel in Western Australia: Nature, v. 226, p. 691-693

Puchtel, I. S., and Humayan, M., 2001, Platinum group element fractionation in a komatiite basalt lava lake: Contributions to Mineralogy and Petrology, v. 65, p. 2979-2993.

Redman, B. A., and Keays, R. R., 1985, Archaean basic volcanism in the eastern Goldfields Province, Yilgarn Block, Western Australia: Precambrian Research, v. 30, p. 113-152.

Rehkämper, M., Halliday, A. N., Fitton, J. G., Lee, D.-C., Wieneke, M., and Arndt, N. T., 1999, Ir, Ru, Pt, and Pd in basalts and komatiites: new constraints for the geochemical behavior of the platinum-group elements in the mantle: Geochimica et Cosmochimica Acta, v. 63, p. 3915-3934.

Révillon, S., Arndt, N.T., Chauvel, C. and Hallot, E., 2000, Geochemical study of ultramafic and plutonic rocks from Gorgona Island, Colombia: the plumbing system of an oceanic plateau: Journal of Petrology, 41, 1127-1153.

Richards, J.P., 1995, Alkalic-type epithermal gold deposits - a review, in Thompson, J.F.H. (ed.), Magmas, Fluids, and Ore Deposits: Mineralogical Association of Canada, Short Course Series, v. 23, ch. 17, p. 367-400.

Ripley, E.M., 1986, Application of stable isotopic studies to problems of magmatic sulfide ore genesis with special reference to the Duluth Complex, Minnesota, in Friedrich, G., Genkin, A.D., Naldrett, A.J., Ridge, J.D., Sillitoe, R.H., and Vokes, F.M., Eds., Geology and Metallogeny of Copper Deposits: Berlin, Springer-Verlag, p. 25-42.

Ripley, E. M., Lightfoot, P. C., Li, C., and Elswick, E. R., 2003, Sulfur isotopic studies of continental flood basalts in the Noril'sk region: implications for the association between lavas and ore-bearing intrusions: Geochimica et Cosmochimica Acta, v. 67, p. 2805-2817.

Ripley, E. M., Park, Y.-R., Li, C., and Naldrett, A. J., 1999, Sulfur and oxygen isotopic evidence of country rock contamination in the Voisey's Bay Ni-Cu-Co deposit, Labrador, Canada: Lithos, v. 47, p. 53-68.

Shima, H., and Naldrett, A.J., 1975, Solubility of sulfur in an ultramafic melt and the relevance of the system Fe-S-O: Economic Geology, v. 70, p. 960-967.

Sisson, T.W., 2003, Native gold in a Hawaiian alkalic magma: Economic Geology, v. 98; p. 643-648.

Song, X.-Y., Zhou, M. F., Cao, Z. M., Sun, M., and Wang, Y. L., 2003, Ni-Cu-(PGE) magmatic sulfide deposits in the Yangliuping area, Permian Emeishan igneous province, SW China: Mineralium Deposita, v. 38, p. 831-843.

Sproule, R.A., Lesher, C.M., Ayer, J.A., Thurston, P.C., and Herzberg, C.T, 2002, Spatial and temporal variations in the geochemistry of komatiitic rocks in the Abitibi greenstone belt: Precambrian Research, v. 115, p. 153-186.

Sproule, R.A., Lesher, C.M., Houlé, MG., Keays, R.R., Ayer, J.A., and Thurston, P.C., in press, Chalcophile element geochemistry, petrogenesis, and metallogenesis of komatiitic rocks in the Abitibi Greenstone Belt, Canada: Economic Geology.

Stekhin, A. I., 1994, Mineralogy and geochemical characteristics of the $\mathrm{Cu}-\mathrm{Ni}$ ores of the Oktyabr'sky and Talnakh deposits: Ontario Geological Survey Special Volume 5, p. 217230. 
Sun, S.-S., and Nesbitt, R. W., 1978, Petrogenesis of Archean ultrabasic and basic volcanics: evidence from rare earth elements: Contributions to Mineralogy and Petrology, v. 65, p. 301325.

Tang, Z., 1995, Ore-forming model and geological correlation of the Jinchuan Cu-Ni-(PGEbearing) sulfide deposit: Beijing, Geological Publishing House, 208 pp.

Tornos, F., Casquet, C., Galindo, C., Velasco, F. \& Canales, A. 2001. A new style of Ni-Cu mineralization related to magmatic breccia pipes ina transpressional magmatic arc, Aguablanca, Spain : Mineralium Deposita, 36 (7), 700-706.

Vasil'yev, Y. R., and Zolotukhin, V. V., 1975, Petrologiya ul'trabazitov severa Siberskoy platformy i nekotoryye problemy ikh genezisa (Petrology of the ultrabasites in the North Siberian Platform and some problems of their origin) (in Russian): Nauka, Novosibirsk.

Walker, R. J., Echeverría, L. M., Shirey, S. B., and Horan, M. F., 1991, Re-Os isotopic constraints on the origin of volcanic rocks, Gorgona Island, Colombia: Os isotopic evidence for ancient heterogeneities in the mantle: Contributions to Mineralogy and Petrology, v. 107, p. $150-162$.

Walker, R.J. , Morgan J.W., Horan M.F., Czamanske G.F., Krogstad E.J., Fedorenko V. and Kunilov V.E. 1994, Re-Os isotopic evidence for an enriched-mantle source for the Noril'sktype ore-bearing intrusions, Siberia : Geochimica Cosmochimica Acta 58 , 4179-4197.

Walker, R., Shirey, S. B., and Stecher, O., 1988, Comparative Re-Os, Sm-Nd and Rb-Sr isotope and trace element systematics fro Archean komatiite flows from Munro Township, Abitibi Belt, Ontario: Earth and Planetary Science Letters, v. 87, p. 1-12.

Wendlandt, R.F., 1982, Sulfide saturation of basalt and andesite melts at high pressures and temperatures, American Mineralogist, v. 67, p. 877-885.

Wooden, J. L., Czamanske, G. K., Fedorenko, V. A., Arndt, N. T., Chauvel, C., Bouse, R. M., King, B. W., Knight, R. J., and Siems, D. F., 1993, Isotopic and trace-element constraints on mantle and crustal contributions to Siberian continental flood basalts, Noril'sk area, Siberia: Geochimica et Cosmochimica Acta, v. 57, p. 3677-3704.

Zen'ko, T. E., and Czamanske, G. K., 1994, Tectonic controls on ore-bearing intrusions of the Talnakh ore junction: position, morphology and ore distribution: International Geology Review, v. 36, p. 1033-1057.

Zindler, A., and Hart, S., 1986, Chemical geodynamics: Annual Review of Earth and Planetary Sciences, v. 14, p. 493-571.

\section{Figure captions}

Fig. 1: Diagrams illustrating changes in the temperature and compositions of partial melts of mantle peridotite. (a) Variations in the nature of the partial melt caused by successive melting of the major silicate minerals. (b) Trends showing variations in the concentrations of incompatible lithophile elements, incompatible chalcophile elements ( $\mathrm{Cu}$ and the Pt-group PGE), and compatible chalcophile elements (Ni and the Ir-group PGE). The arrow labeled "sulfide out" indicates schematically the point of total dissolution of residual sulfide liquid (from Keays, 1995, and Rehkämper et al., 1999) for tholeiitic basalts, picrites, and komatiites. (c) Variations in the predicted Pd contents of mantle melts (from Rehkämper et al., 1999) and measured Pd contents of various magma 
types. The concentrations in oceanic island basalt (OIB), mid-ocean ridge basalt (MORB) and komatiite correspond to those predicted. The solid line is the predicted curve in a triangular melting regime, as exists beneath a spreading center such as a mid-ocean ridge (Langmuir et al., 1992); the dashed curve is that of a columnar melting regime, as in a mantle plume (see Rehkämper et al., 1999 for details).

Fig. 2: Diagram showing the La and Sm contents of various types of mafic-ultramafic magmas normalized to 15 percent $\mathrm{MgO}$ by the addition or subtraction of olivine. The solid line shows the calculated variation in the La and Sm contents of magmas produced by equilibrium partial melting of mantle peridotite (primitive mantle of Hofmann, 1989). The tic marks indicate percentage melting. Note that meimechites and alkali picrites are produced by less than 1 percent partial melting and should, according to the predicted curves in Fig. 1b, c, have low contents of chalcophile elements.

Fig. 3: Schematic diagram showing $\mathrm{S}$ contents of a komatiitic and a basaltic magma at their sites of melting and at the surface (from Mavrogenes and O'Neil, 1999). The komatiite acquires about $600 \mathrm{ppm} \mathrm{S}$ at the site of melting, but because of the strong pressure dependence of S solubility is capable of dissolving about $2700 \mathrm{ppm}$ at the surface. Such magma therefore is strongly undersaturated in $\mathrm{S}$ at crustal levels.

Fig. 4: Diagram showing the paths followed rising, melting mantle material during the formation of various types of mafic and ultramafic magma. The degree of partial melting, in percent, is indicated on the dashed curved lines between the solidus and liquidus. The ascent paths of solid or partially melting source peridotite are shown as solid, steeply sloping lines; the ascent paths of melt by dashed lines. The stars represent the pressure and temperature conditions at which the magma separates from its source (modified from Arndt, 2003). Basalt forms by moderate-degree melting at shallow levels; alkali picrite by low-degree melting at intermediate depth; and tholeiitic picrite by high-degree melting at intermediate depth. Al-undepleted komatiite forms by high-degree melting at great depth, and Al-depleted komatiite forms by moderate-degree melting at extreme depth.

Fig. 5: Variations in the concentrations and ratios of PGE and La, plotted against the $\mathrm{MgO}$ contents of mafic and ultramafic magmas. In the figures on the left, the large grey symbols represent the compositions of picrites from the Noril'sk region. The squares labeled "Gud picrites" are the alkali Gudchikhinsky picrites; the circles labeled "Tuk picrites" are the tholeiitic Tuklonsky picrites. The data in the Re and Os vs MgO diagrams come from studies of Re-Os isotopic compositions and those in the Ir and Pd vs $\mathrm{MgO}$ diagrams from analyses of PGE (but not Re or Os); the data sets therefore are not identical in the two figures. Note that the levels of Os and Ir in alkali picrites are as high as those in komatiites; and the levels of Re and Pd are higher than those of Al-depleted komatiite but lower than levels in Al-undepleted komatiite. Principal sources of data: Arndt and Nesbitt (1984), Arndt et al. (1995, 1998, 2003), Brügmann et al. (1987, 1993), Gangopadhyay and Walker (2003), Horan et al. (1995), Jochum et al. (1990), Keays (1982, 1995) Lahaye et al. (1995), Lesher and Arndt (1995), Lightfoot and Hawkesworth (1997), Lightfoot et al. (1990, 1994), Maier et al. (2003), Momme et al. (2002), Naldrett et al. (1992, 1996), Pik et al., 1998, 1999), Puchtel and Humayan. (2001), Redman and 
Keays (1985), Rehkämper et al., (1999), Sproule et al. (2002), Sun and Nesbitt (1978), Walker et al. (1988, 1991, 1992, 1994, 2002), Wooden et al. (1993).

Fig. 6: Model for the emplacement of mineralized and weakly-mineralized intrusions in the Noril'sk-Talnakh region (from Arndt et al. 2003). The diagram illustrates evolution of the magmatic system following the emplacement of the lower series of alkaline magmas, the Gudchikhinsky picrites, and the Tuklonsky picrites, which probably took no direct part in the ore-forming process. The path A to B represents the emplacement of the lower Talnakh intrusions and Nadezhdinsky basalts. The parental magmas became contaminated with granitic crustal rocks in a mid-crustal magma chamber. They segregated sulfides that remained in the chamber and PGE-poor magmas ascended to the surface, probably without forming ore deposits. The path $\mathrm{C}$ to $\mathrm{D}$ is that of magmas that were less contaminated in the mid-crustal chamber and remained relatively rich in chalcophile elements as they ascended towards the surface. They formed the ore bodies when they assimilated $\mathrm{S}$ from evaporitic sediments. The path $\mathrm{E}$ is that of basalts higher in the volcanic pile, which took no part in the ore-forming process.

Fig. 7: Variation diagrams showing the contrasting compositions of lavas from the Kotuy region in the northeast of the Siberian flood volcanic province. Note the contrasting compositions of the tholeiitic basalts (black squares) and the meimechitic to trachytic lavas of the alkali series (open squares) (from Arndt et al., 1998).

Fig. 8: Variation diagrams comparing the compositions of sills peripheral to the Bushveld Complex (from Maier et al., 2003), siliceous high-Mg basalts from the Kambalda region (from Redman and Keays, 1985), and boninitic lavas (Keays, 1995; Woodland et al., 2004). Also shown are fields for komatiites and alkali and tholeiitic basalts. Note the high Ir and Pd contents of both the Bushveld sills, which are believed to represent magma parental to the Bushveld Complex, and the Kambalda basalts, which were interpreted by Arndt and Jenner (1986) as contaminated komatiites. The data show that komatiite can become highly contaminated with granitic crust without reaching $\mathrm{S}$ saturation and losing PGE. The data support the hypothesis that the Bushveld magmas are contaminated komatiites and not boninites, which, at a given $\mathrm{MgO}$ content, have lower PGE contents. 
Table 1. Classification of primary mineralization types in magmatic Ni-Cu-PGE deposits (adapted from Lesher and Keays, 2002).

\begin{tabular}{|c|c|c|c|c|c|c|c|}
\hline Type & \multicolumn{3}{|c|}{$\mathbf{I}$} & \multicolumn{3}{|c|}{ II } & III \\
\hline Localization & \multicolumn{3}{|c|}{ basal } & \multicolumn{3}{|c|}{ internal, strata-bound } & internal, stratiform \\
\hline Form & $\begin{array}{l}\text { massive-interstitial- } \\
\text { (disseminated) layers }\end{array}$ & $\begin{array}{l}\text { veins and } \\
\text { stockworks }\end{array}$ & pods/veins & blebby & interstitial & cloudy & massive to disseminated \\
\hline $\begin{array}{l}\text { Ore } \\
\text { Textures }\end{array}$ & $\begin{array}{c}\text { massive, } \\
\text { net-textured, } \\
\text { disseminated; may } \\
\text { contain xenoliths or } \\
\text { xenomelts }\end{array}$ & $\begin{array}{l}\text { massive to } \\
\text { disseminated }\end{array}$ & $\begin{array}{l}\text { massive, } \\
\text { stockwork, and/or } \\
\text { disseminated }\end{array}$ & $\begin{array}{l}\text { blebby, } \\
\text { globular }\end{array}$ & $\begin{array}{l}\text { intercumulus, } \\
\text { interstitial to lobate }\end{array}$ & $\begin{array}{l}\text { intercumulus, } \\
\text { interstitial }\end{array}$ & $\begin{array}{c}\text { disseminated, rarely net-textured } \\
\text { or massive }\end{array}$ \\
\hline $\begin{array}{l}\text { Timing and } \\
\text { Paragenesis of } \\
\text { Mineralization }\end{array}$ & \multicolumn{3}{|c|}{$\begin{array}{l}\text { early magmatic, segregated prior to or } \\
\text { during emplacement of host unit }\end{array}$} & \multicolumn{2}{|c|}{$\begin{array}{c}\text { intermediate magmatic, segregated during } \\
\text { intermediate stages of crystallization } \\
\text { of host unit }\end{array}$} & $\begin{array}{l}\text { late magmatic, } \\
\text { segregated during } \\
\text { final stages of } \\
\text { crystallization of } \\
\text { host unit }\end{array}$ & $\begin{array}{l}\text { intermediate to late magmatic, } \\
\text { segregated during intermediate to } \\
\text { final stages of crystallization } \\
\text { of host unit }\end{array}$ \\
\hline $\begin{array}{l}\text { Examples of } \\
\text { Ni-Cu-PGE } \\
\text { Deposits }\end{array}$ & $\begin{array}{l}\text { Kambalda contact } \\
\text { ores, Noril'sk- } \\
\text { Talnakh massive } \\
\text { ores, Raglan contact } \\
\text { ores, Sudbury contact } \\
\text { ores, Voisey's Bay } \\
\text { Ovoid }\end{array}$ & $\begin{array}{c}\text { Sudbury } \\
\text { footwall ores, } \\
\text { Kambalda } \\
\text { interpillow, } \\
\text { interbreccia, } \\
\text { and } \\
\text { interspinifex } \\
\text { ores }\end{array}$ & $\begin{array}{l}\text { Sudbury offset } \\
\text { ores, Voisey's Bay } \\
\text { Eastern Deeps }\end{array}$ & $\begin{array}{c}\text { Damba-Silwane, } \\
\text { Kambalda } \\
\text { Durkin and } \\
\text { Otter shoots, } \\
\text { Sudbury contact } \\
\text { ores, Noril'sk- } \\
\text { Talnakh picritic } \\
\text { ores }\end{array}$ & $\begin{array}{l}\text { Duluth, Mt. Keith, Dumont, } \\
\text { Perseverance Main, parts of } \\
\text { most other deposits }\end{array}$ & $\begin{array}{l}\text { Katinniq, } \\
\text { Perseverance Main, } \\
\text { parts of most other } \\
\text { deposits }\end{array}$ & $\begin{array}{l}\text { Subeconomic (Delta sill, Romeo } \\
\text { II sill, Fred's Flow, Boston } \\
\text { Creek sill) }\end{array}$ \\
\hline $\begin{array}{l}\text { Examples of } \\
\text { PGE Deposits }\end{array}$ & Bushveld Plat Reef? & None known? & None known? & None known? & None known? & None known? & $\begin{array}{l}\text { Bushveld Merensky Reef, } \\
\text { Stillwater JM Reef, } \\
\text { (Munni Munni) }\end{array}$ \\
\hline
\end{tabular}


Table 2: Concentrations and ratios of PGE in selected mafic and ultramafic rocks

\begin{tabular}{|c|c|c|c|c|c|c|}
\hline & $\begin{array}{c}\mathrm{Pd} \text { or } \mathrm{Re} \\
\text { concentration }\end{array}$ & $\begin{array}{c}\text { Ir or Os } \\
\text { concentration }\end{array}$ & $\begin{array}{l}\mathrm{Pd} / \mathrm{Ir} \text { or } \\
\mathrm{Re} / \mathrm{Os}\end{array}$ & $\begin{array}{l}\text { Concentration of } \\
\text { incompatible } \\
\text { lithophile elements }\end{array}$ & $\begin{array}{l}\text { Degree of melting } \\
\text { predicted from } \\
\text { lithophile elements }\end{array}$ & $\begin{array}{c}\text { Sulfide } \\
\text { saturated }\end{array}$ \\
\hline MORB & very low & low & high & very low & moderate & yes \\
\hline Alkali basalt & $\begin{array}{c}\text { low to very } \\
\text { low }\end{array}$ & low to very low & low & high & low & yes \\
\hline $\begin{array}{l}\text { Continental flood } \\
\text { basalt }\end{array}$ & very high & moderate & very high & moderate & moderate & no \\
\hline $\begin{array}{l}2.7 \mathrm{Ga} \text { Al-undepleted } \\
\text { komatiite }\end{array}$ & high & very high & low & very low & very high & no \\
\hline $\begin{array}{l}3.5 \mathrm{Ga} \text { Al-depleted } \\
\text { komatiite }\end{array}$ & low & high & very low & low & high & no \\
\hline $\begin{array}{l}\text { Alkali picrite \& } \\
\text { meimechite }\end{array}$ & moderate & high & very low & very high & very low & no \\
\hline
\end{tabular}


Table 3: Calculated degrees of melting for komatiite and meimechite

$\begin{array}{lccc}\text { Source } & \text { Primitive mantle }^{1} & \text { Depleted mantle } & \text { Enriched mantle } \\ \mathrm{La}(\mathrm{ppm}) & 0.61 & 0.2 & 6 \\ \mathrm{Yb}(\mathrm{ppm}) & 0.41 & 0.4 & 0.45 \\ \mathrm{La} / \mathrm{Yb} & 1.48 & 0.5 & 13.3 \\ \text { Olivine }^{2} & 55 & 55 & 55 \\ \text { Orthopyroxene }_{\text {Clinopyroxene }} & 20 & 30 & 20 \\ \text { Garnet } & 15 & 15 & 15 \\ & 10 & 0 & 10\end{array}$

Komatiite KAL-1 $\quad 15 \%$ critical $^{3} \quad 50 \%$ batch melting melting of primitive of depleted mantle mantle

$\begin{array}{llll}\mathrm{La}(\mathrm{ppm}) & 0.4 & 0.42 & 0.40 \\ \mathrm{Yb}(\mathrm{ppm}) & 0.8 & 0.85 & 0.75 \\ \mathrm{La} / \mathrm{Yb} & 0.5 & 0.49 & 0.53\end{array}$

Average meimechite $0.1 \%$ batch melting $11 \%$ batch melting from Arndt et al. of primitive mantle of enriched mantle (1998)

$\begin{array}{lccc}\mathrm{La}(\mathrm{ppm}) & 50 & 55 & 51 \\ \mathrm{Yb}(\mathrm{ppm}) & 1 & 0.80 & 0.82 \\ \mathrm{La} / \mathrm{Yb} & 50 & 69 & 62\end{array}$

Calculations were made using the formulae and melting parameters of Gurenko and Chaussidon (1995), Arndt et al. (1998) and Révillon et al. (2000). ${ }^{1}$ values from Hofmann (1988); ${ }^{2}$ mineral proportions in the source, in percent; ${ }^{3}$ critical melting is a variant of fractional melting in which a fraction of melt, $1 \%$ in this example, is retained in the source. Note that the values listed in the table represent possible solutions only: very different results can be obtained using other equally legitimate choices of melting parameters (proportion of garnet in the source and in the melt; proportion of retained melt, etc). 
Table 4. Estimated parental magmas of various magmatic ore deposits and volcanic provinces

\begin{tabular}{|c|c|c|c|c|c|c|c|}
\hline $\begin{array}{l}\text { Deposit or } \\
\text { region }\end{array}$ & Kambalda & Noril'sk & Noril'sk & Voisey's Bay & Bushveld & Ethiopia & Kola Peninsula \\
\hline TYPE & $\begin{array}{l}\text { Spinifex-textured } \\
\text { komatiite }\end{array}$ & $\begin{array}{c}\text { Tuklonsky } \\
\text { picrite }\end{array}$ & $\begin{array}{l}\text { Gudchikhinsky } \\
\text { picrite }\end{array}$ & $\begin{array}{c}\text { Mafic } \\
\text { intrusion } \\
\text { (HAG1) }\end{array}$ & $\begin{array}{c}\text { B1-type } \\
\text { marginal sill }\end{array}$ & $\begin{array}{l}\text { Alkali } \\
\text { picrite }\end{array}$ & Fe-picrite \\
\hline Ref & $\begin{array}{c}\text { Lesher \& Arndt } \\
\text { (1995) }\end{array}$ & $\begin{array}{l}\text { Wooden et al. } \\
\text { (1993) }\end{array}$ & $\begin{array}{l}\text { Wooden et al. } \\
\text { (1993) }\end{array}$ & $\begin{array}{l}\text { Scoates \& } \\
\text { Mitchell }\end{array}$ & $\begin{array}{l}\text { Maier et al. } \\
\quad(2000)\end{array}$ & $\begin{array}{l}\text { Pik et al. } \\
\text { (1998) }\end{array}$ & $\begin{array}{l}\text { Hanski et al. } \\
\text { (1992) }\end{array}$ \\
\hline $\mathrm{SiO}_{2}$ & 45.1 & 48.2 & 48.3 & 48.3 & 55.4 & 44.0 & 47.5 \\
\hline $\mathrm{TiO}_{2}$ & 0.30 & 0.8 & 1.5 & 1.0 & 0.3 & 4.4 & 2.3 \\
\hline $\mathrm{Al}_{2} \mathrm{O}_{3}$ & 6.4 & 12.8 & 10.0 & 17.2 & 11.3 & 7.6 & 7.5 \\
\hline $\mathrm{Fe}_{2} \mathrm{O}_{3}$ & 11.5 & 11.2 & 13.5 & 11.9 & 10.7 & 14.2 & 15.4 \\
\hline $\mathrm{MnO}$ & 0.14 & 0.2 & 0.2 & 0.2 & 0.2 & 0.2 & 0.2 \\
\hline $\mathrm{MgO}$ & 30.8 & 15.7 & 16.5 & 9.3 & 13.3 & 14.2 & 14.8 \\
\hline $\mathrm{CaO}$ & 5.9 & 9.4 & 8.4 & 9.2 & 6.3 & 10.1 & 11.3 \\
\hline $\mathrm{Na}_{2} \mathrm{O}$ & 0.1 & 1.2 & 1.3 & 2.5 & 1.4 & 1.6 & 0.2 \\
\hline $\mathrm{K}_{2} \mathrm{O}$ & 0.01 & 0.4 & 0.2 & 0.4 & 0.8 & 1.1 & 0.2 \\
\hline To analyses & 1 & 6 & 14 & 1 & 3 & 12 & 1 \\
\hline
\end{tabular}



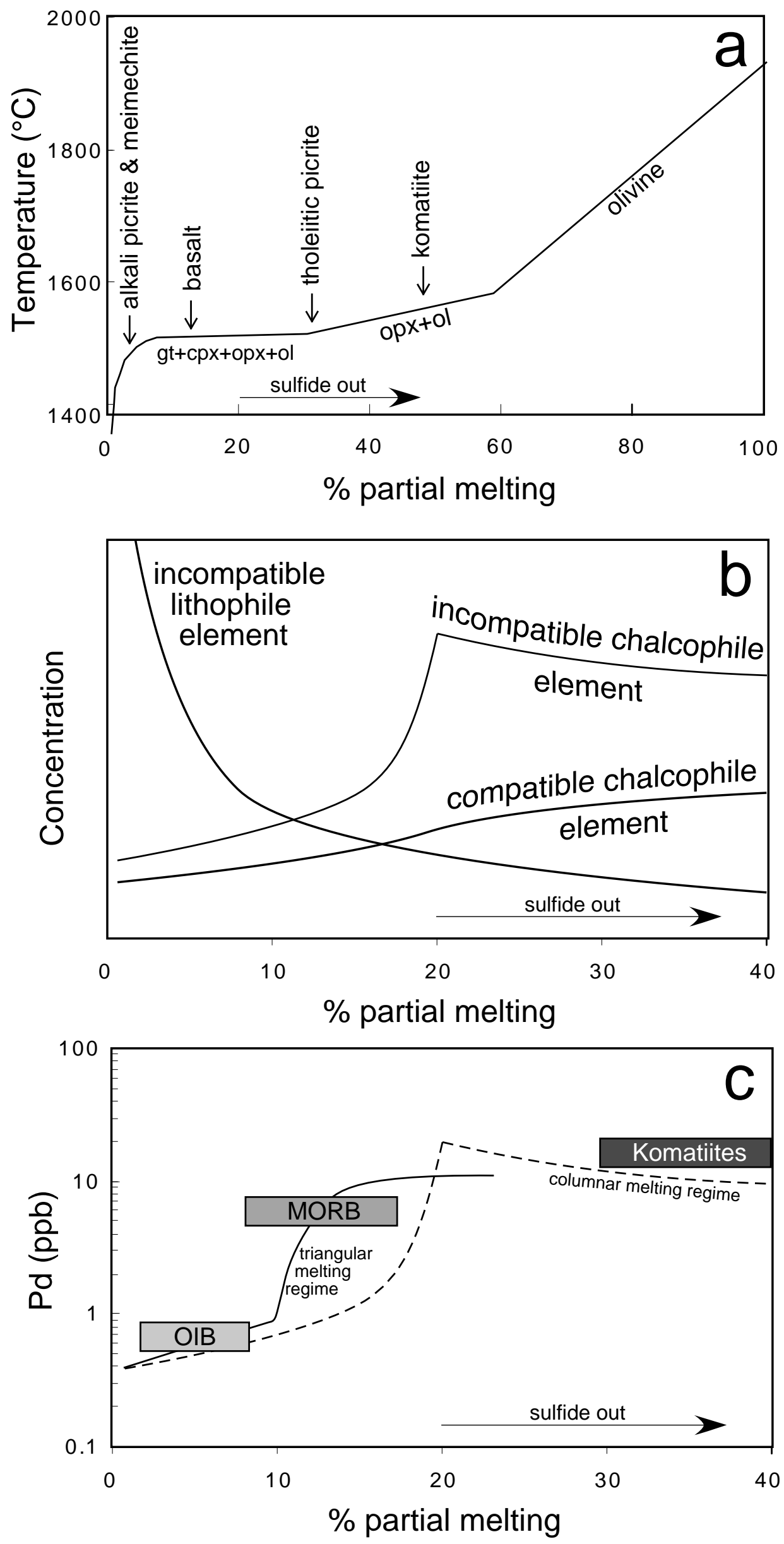

Fig 1 


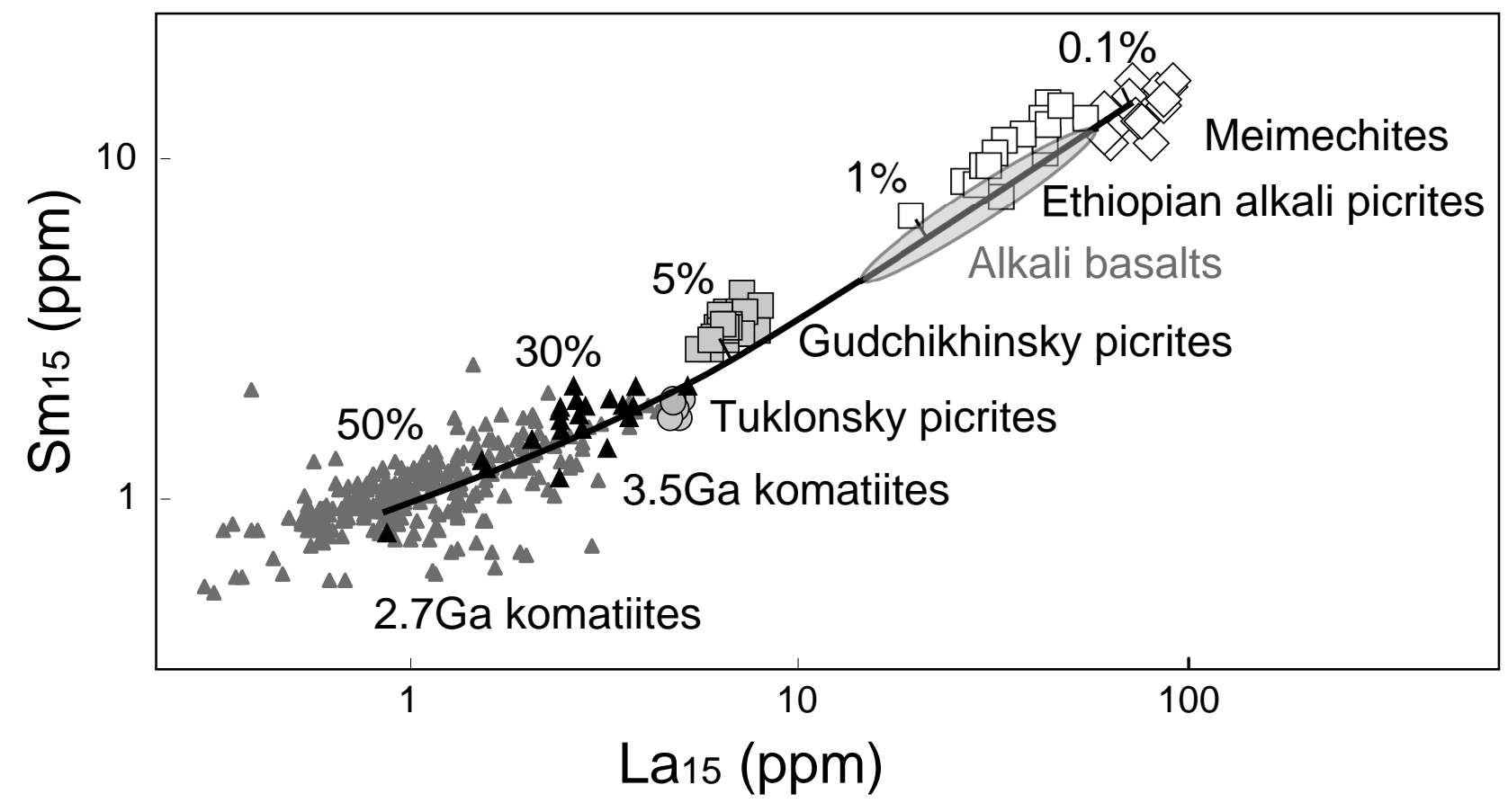

Fig 2 


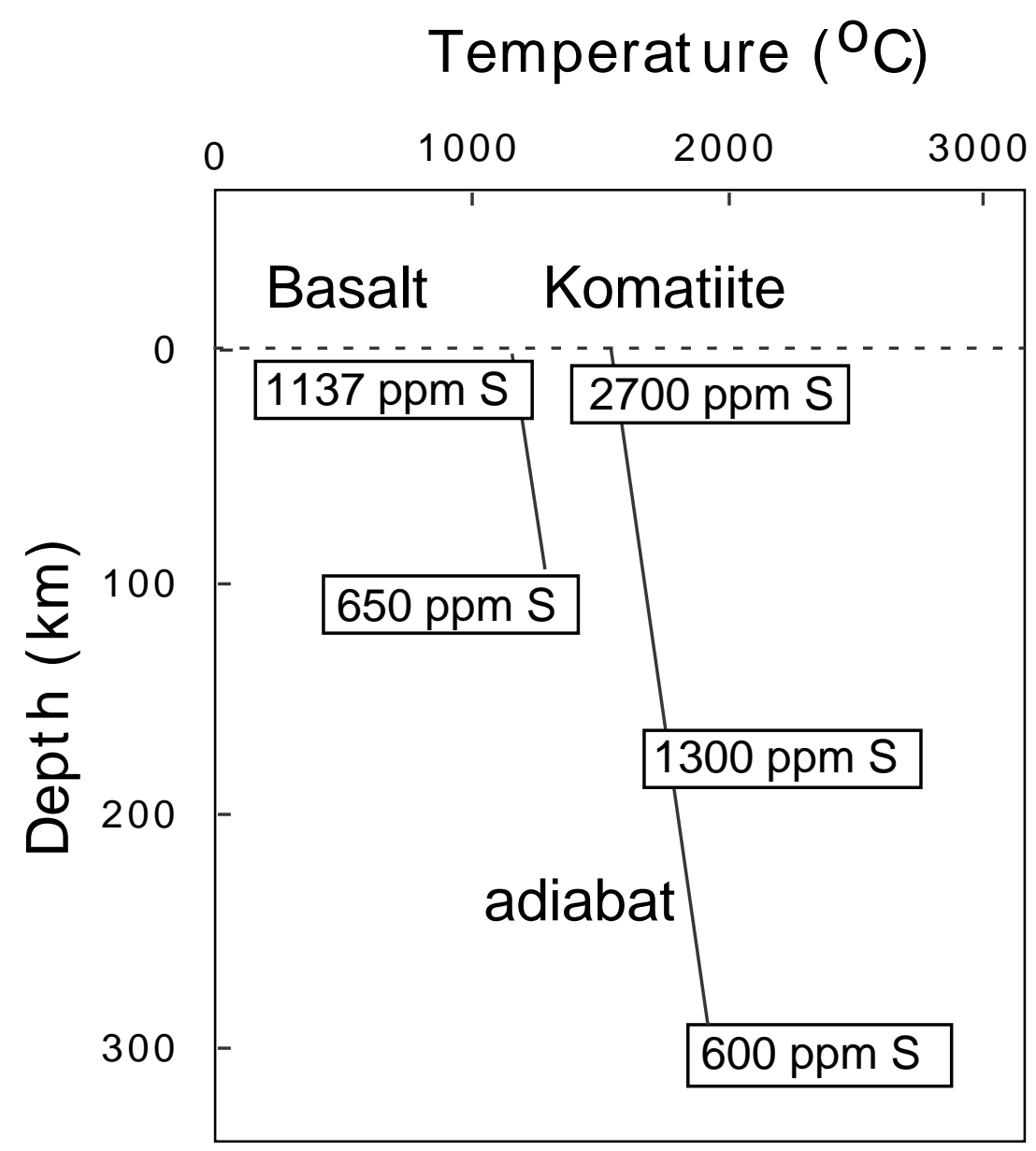

Fig 3 


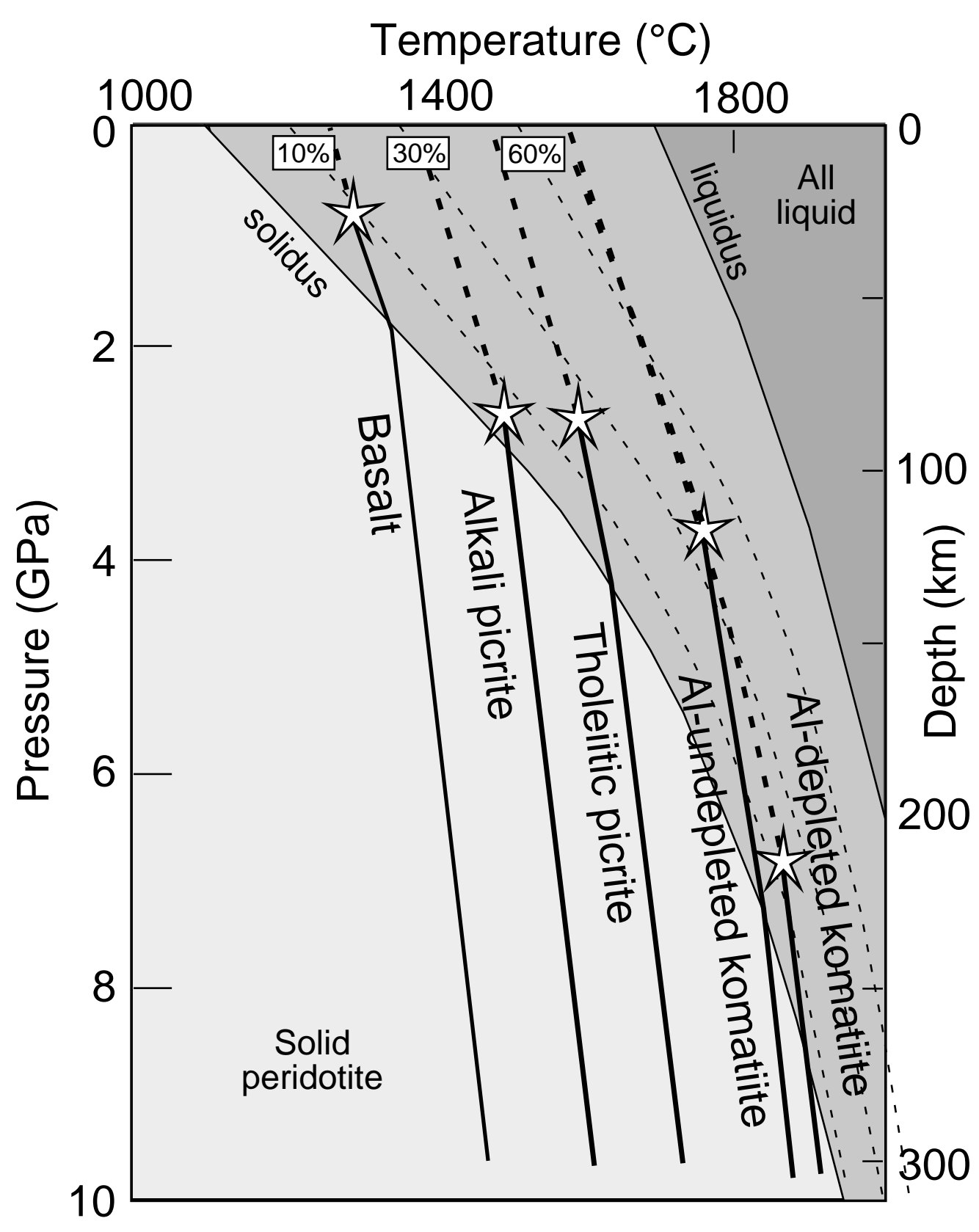

Fig 4 


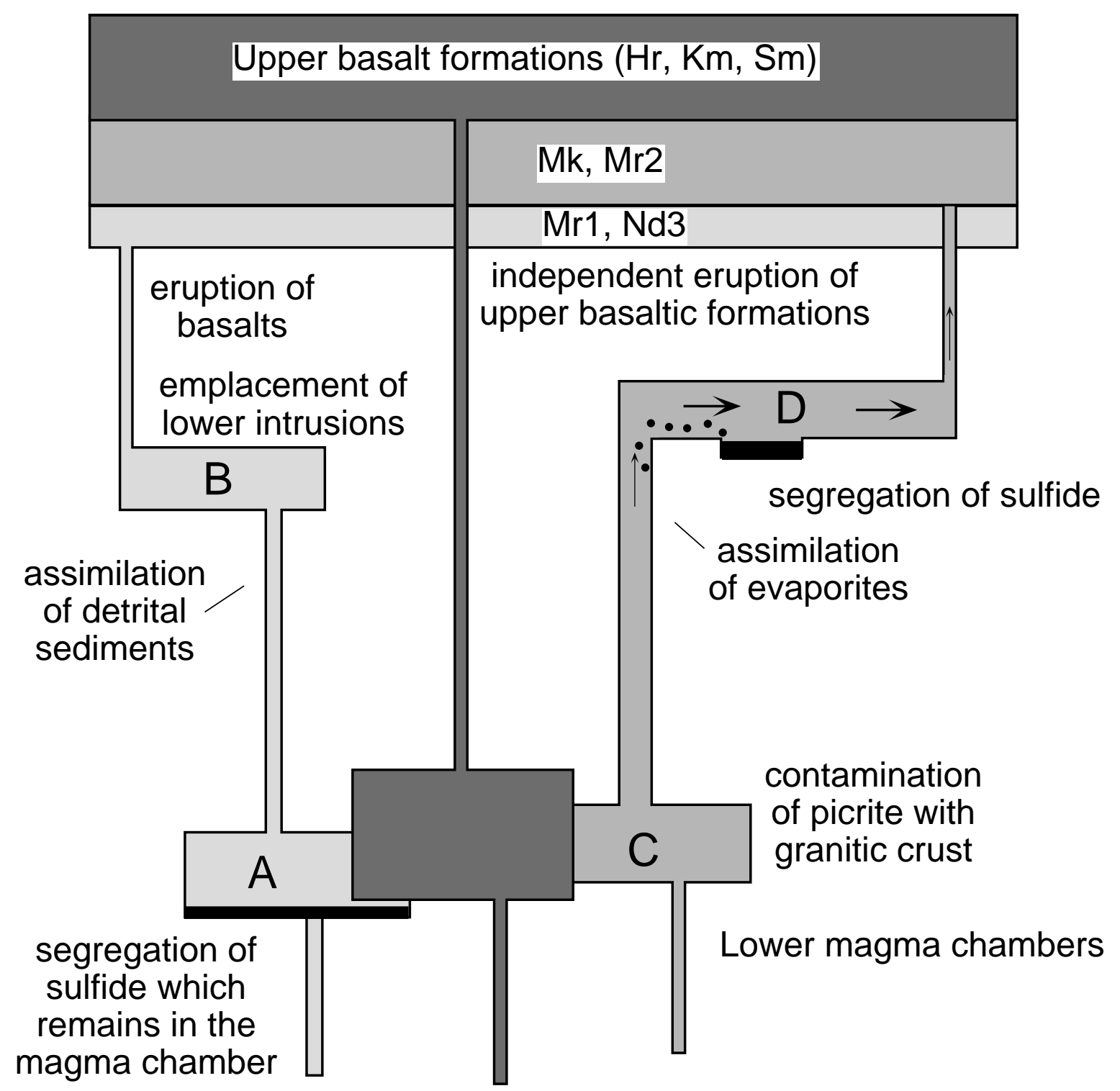

Fig 7 

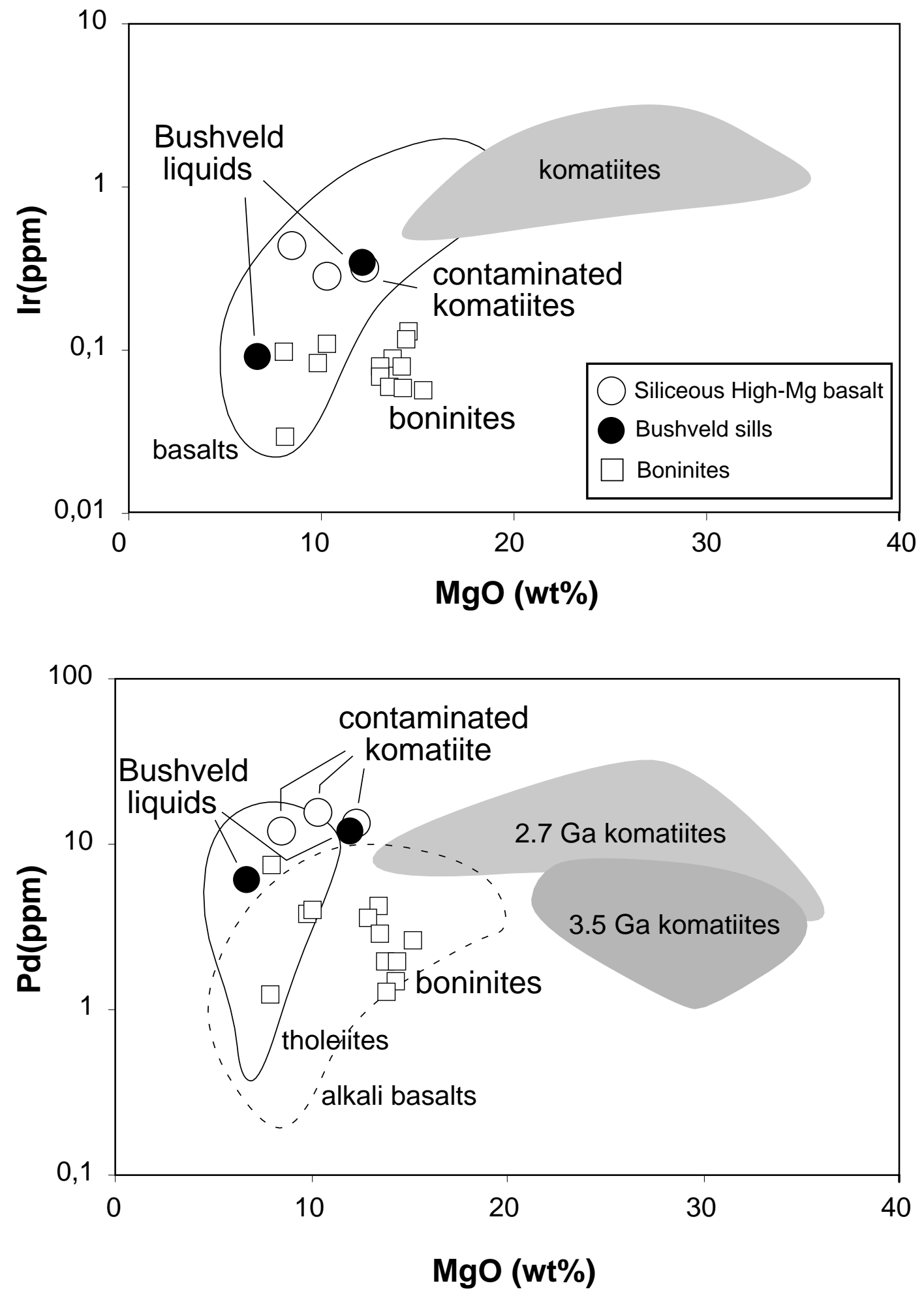

Fig 8 